هتطلبات تنهية ههارات التفكير الابتكاري لدي الطلائع بمراكز الشباب دراسة هن هنظور طريقة تنظيم المتهمع بهرئ

إعداد

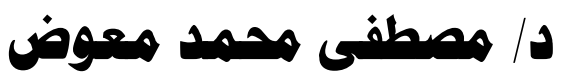

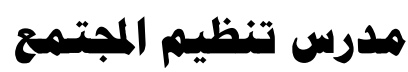

بالمعهد العالى للخدمة الاجتهاعية بالقاهرة 


\section{العدد الثانى والعشرون}

مجلة كلية الخدمة الاجتماعية للار اسات و البحوث الاجتماعية - جامعة كـ 
تتبوأ الطفولة مكان الصدارة في مراحل النمو المختلفة لأنها شديدة التأثير على مراحل النمو التالية وعلى شخصيات الاطفال وسلوكياتهم ونضجهم، ويعد تتمية الابتكار عملية تتم وفق نمو الفرد من الصغر، ووفق اشباع احتياجاته الاساسية والنفسية والتعليمية والاجتماعية، لذلك تقوم على تتمية الابتكار وتربيته عدة مؤسسات منذ لصغر كالأسرة والروضة والمدرسة ومركز الشباب وجميع هذه العناصر معنية بتنمية الابتكار وتهيئة الظروف والعوامل المناسبة التى تعزز وتسهم في تطويره وتتميته وخاصة ان الابتكار في جوهرة استعداد نفسي كامن يمكن ان يزدهر ويستمر عندما تهيء لله الظروف المناسبة وهذا ما يؤكد على اهمية تتمية مهارات الابتكار لدي فئة الطلائع، ويؤكد على اهمية مراكز الشباب في القيام بذلك الدور، لذلك فقد هدفت الدراسة الى تحديد متطلبات تتمية مهارات التقكير الابتكاري لدي الطلائع بمراكز الثباب وقد قسمت الدراسة تلك المتطلبات الى متطلبات ادارية ومتطلبات متعلقة بالبرامج الموجهة للطلائع ومتطلبات تمويلية بالإضافة الى المتطلبات التكنولوجية، وقد انتمت هذه الدراسة الى لى نمط الدر اسات الوصفية واستخدمت منهج المسح الاجتماعي بنوعية واستخدمت أداتي الاستبيان

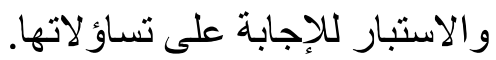
الكمات المفتاحية: متطلبات، مهار ات التفكير الابتكاري، الطلائع. 


\section{Abstract:}

Childhood takes center stage in the various stages of growth because it has a strong influence on the following stages of growth and on the personalities, behaviors and maturity of children, and the development of innovation is a process that takes place according to the growth of the individual from childhood, and according to the satisfaction of his basic, psychological, educational and social needs. Such as the family, kindergarten, school, youth center, and all these elements are concerned with developing innovation and creating the appropriate conditions and factors that enhance and contribute to its development and development, especially that innovation is in the gem of a potential psychological readiness that can flourish and continue when appropriate conditions are created for it, and this underlines the importance of developing innovation skills among the avantgarde class, And stresses the importance of youth centers in 0 carrying out this role, so the study aimed to define the requirements for developing the innovative thinking skills of the pioneers in youth centers. The study divided those requirements into administrative requirements and requirements related to the programs directed to obedience and financing requirements in addition to the technological requirements. This study belonged to Type descriptive studies and social survey methodologies were used qualitatively and tools were used $\mathrm{J}$ questionnaire and inquiry to answer her questions.

Keywords: requirements, innovative thinking skills, Vanguards. 


\section{اولاً: هشكلة الدراسة:}

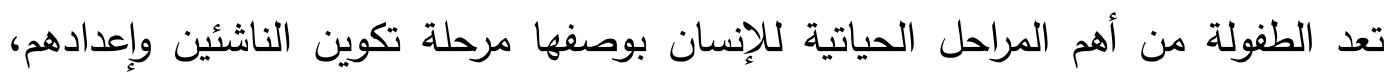
ففيها يتم غرس الجذور الأولي للشخصية وتشكيل العادات والاتجاهات ونمو الميول

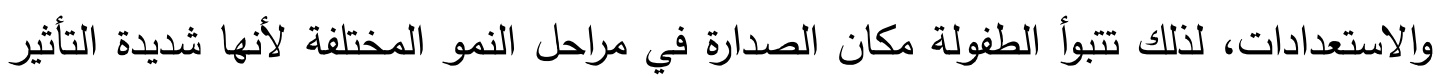
على عوامل النمو التالية وعلى شخصيات الاطفال وسلوكياتهم ونضجهم. (زيدان،2004، ص200)

وفى ضوء الاهتمام المتزايد بمرحلة الطفولة وما يحدث فيها من تغيرات وخاصة المرحلة العمرية 10 : 18 سنة وهي فترة الطفولة المتأخرة حيث يحدث تقدم في المهارات الجسمية والعقلية والاجتماعية وينعكس ذلك على سلوك الطفل، ويحدث تحول معرفي هام

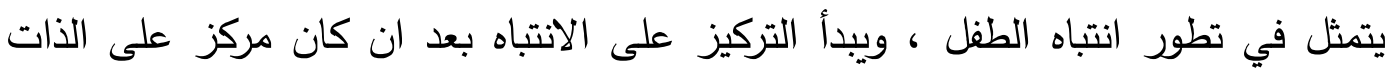

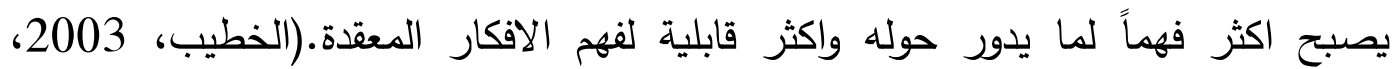
ص291)

وقد أكدت دراسة(Leiterman, 2013 ) أن فئتي الطلائع والثباب في الوقت المعاصر تعد قوة حقيقية يجب أن نتعامل معها بثكل إيجابي مع ضرورة توفير كافة الدقومات التي تعظم الاستفادة من قدراتهم وتوفير كافة المنطلبات اللازمة للارتقاء بتلك الفئة

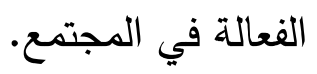

وعلى ذلك فقد تولت الدولة مسئولية إعداد وتتمية شخصية الطلائع من جميع الجوانب، فقد وضع المجلس الاعلى للثباب منذ إنشائه تأهيل الطلائع وتغعيل مشاركتهم في

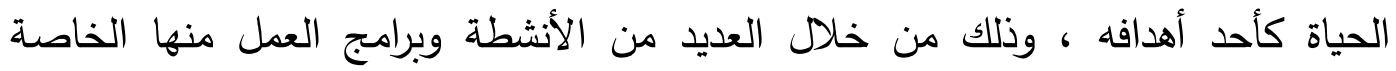

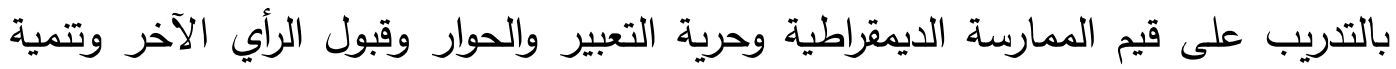

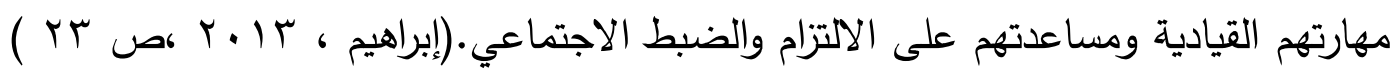

وتعد مراكز الشباب أحد المؤسسات الاجتماعية التربوية الاختيارية التي تساعد الشباب

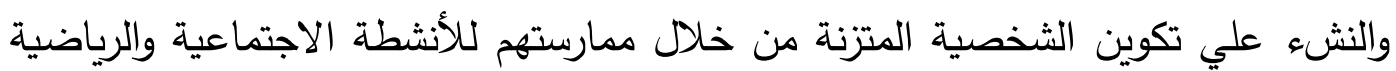

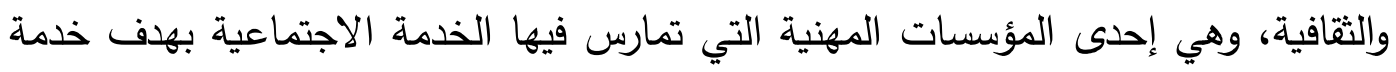

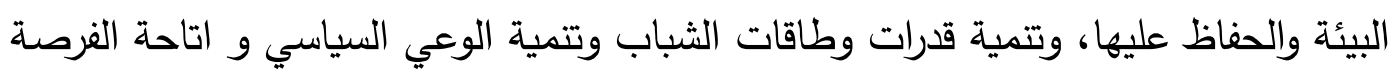
للثباب للمشاركة الفعالة والجادة في المشروعات البيئية والخدمة العامة التي يقدمها مركز 
الثباب علي المستوي المحلي والتي يمكن استثارها في إكساب الثباب السلوك السياسي الايجابي ونبذ السلوك السلبي، وتتتشر مراكز الشباب في جميع أنحاء الدولة لتقديم خدماتها

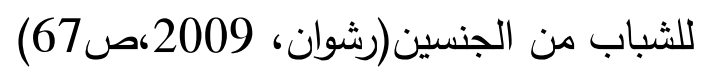

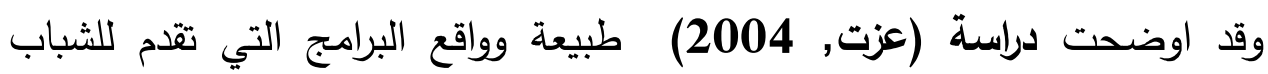

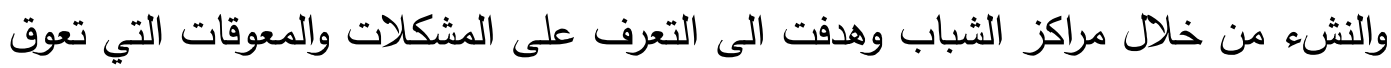
تتفيذ البرامج الترويحية للشباب. استخدمت الدراسة المنهج الوصفي وتم اختيار عينة من 9

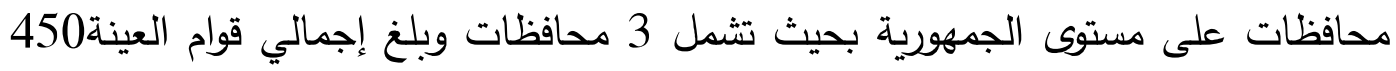
عضو، واعتمدت الدراسة علي تحليل الوثائق والسجلات، الاستبيان، الدقابلة الثخصية، وأوصت الدراسة بأنه لابد أن تتضمن خطة مراكز الثباب برامج تتناسب مع احتياجات

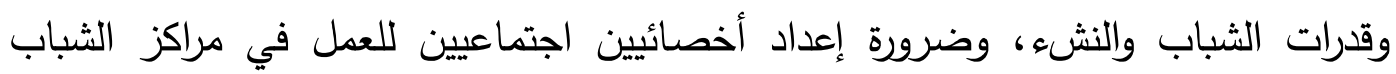
والأندية الرياضية. ودعم مراكز الثباب بالقيادات المؤهلة علمياً.

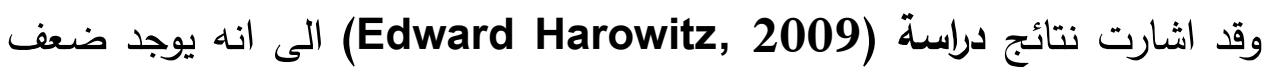
اهتمام الطلائع بالمشاركة والثعور بالاغتراب بالإضافة إلى الإحباط واللامبالاة الذي يعانوا لتانها

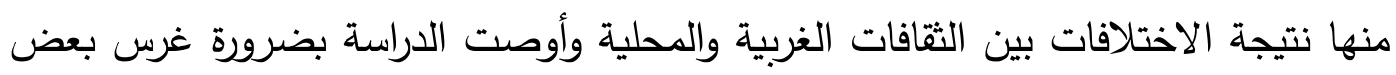
القيم في نفوسهم كقيمة المشاركة وتحمل المسئولية واحترام الآخر .

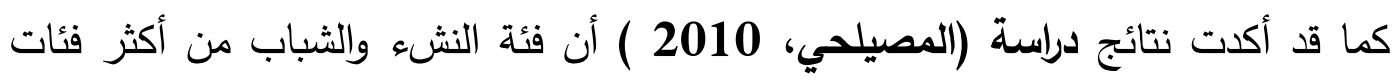

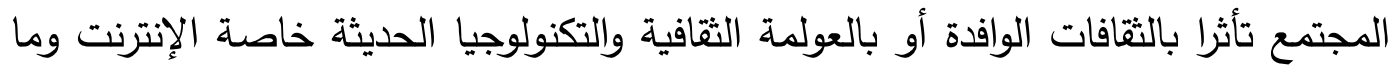
توفره خدمة الثات وتأثرها على قيم النشه والثباب ومنها قيمة المشاركة، والانتماء، وتحمل باتهل

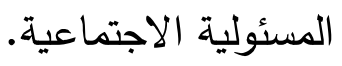

وتؤكد (الزقاوي، 2001، صايه 35) انه لا يختلف اثنان ان الانسان في العصر

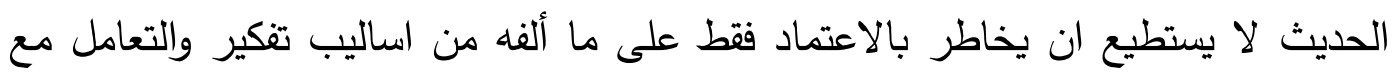

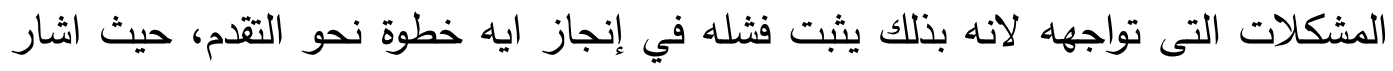

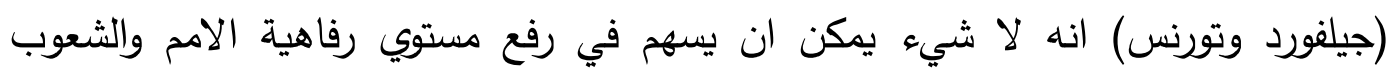

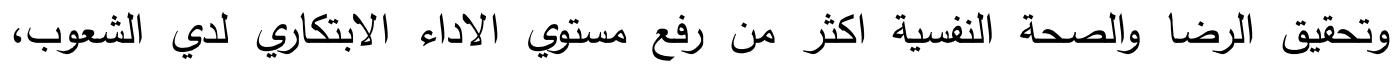
فالاهمام بالابتكار والدراسات الابتكارية لم تكن وليدة الصدفة، بل كان نتيجة حتمية لطبيعة

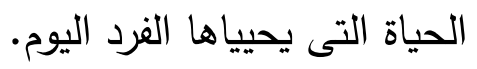




\section{مجلة كلية الخدمة الاجتماعية للار اسات و البحوث الاجتماعية - جامعة لمبرم}

وتؤكد دراسة (جمل، 2005) أن التفكير الابتكاري ضرورة للتكيف مع متغيرات

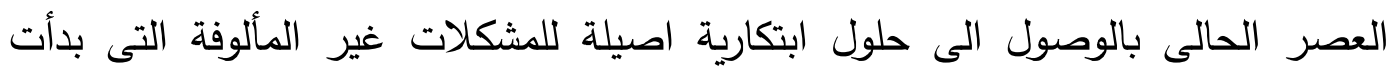
بالانتشار والظهور في العالم الذي يعتبر التغيير سمته الاساسية.

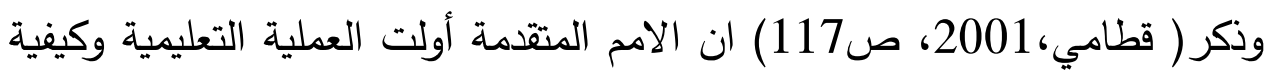
تتمية أساليب التفكير لدي ابنائها جل اهتمام وتتاولها الباحثون بالدراسة من مختلف جوانبها الفيا

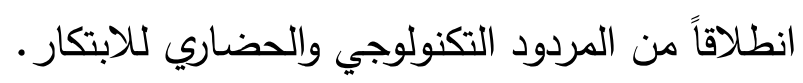
ولان تنمية الابتكار عملية تتم وفق نمو الفرد من الصغردو، ووفق الشباع احتياجاته الاساسية والنفسية والتعليمية والاجتماعية، لذلك تقوم على تلى تتمية الابتكار وتربيته عدة عند

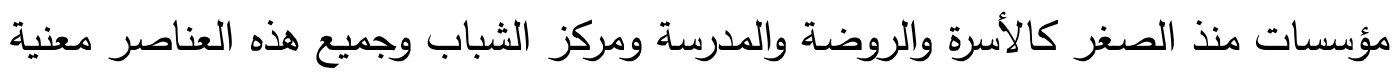
بتنمية الابتكار وتهيئة الظروف والعوامل المناسبة التي تعزز وتسهم في تطويره وتتميته

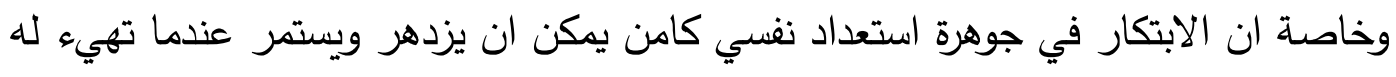

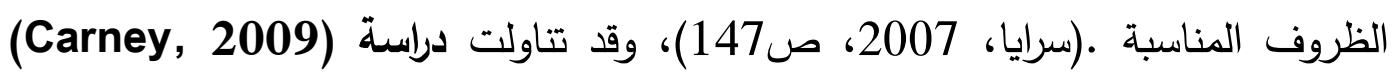
تصورات الاجيال الدختلفة اتجاه الابتكار حيث كان غرض الدراسة تحديد اكثر الاجيال ميلاً

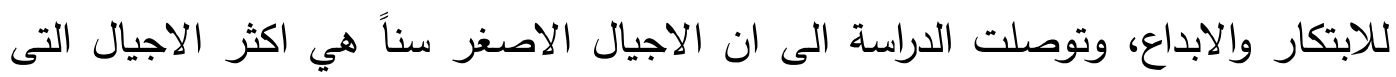

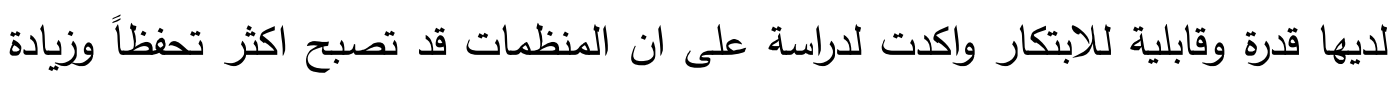

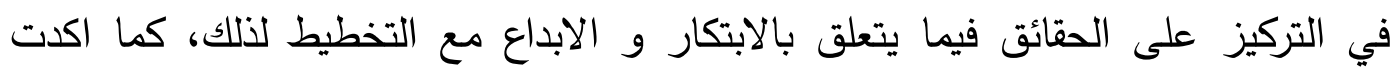

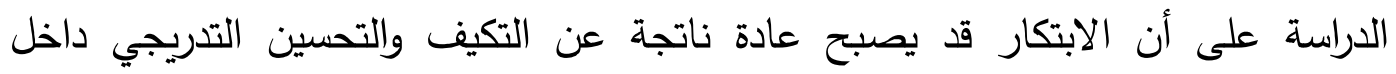
المنظمات .

لذل فقد اوصي (David, \& other ,2012,p324) بضرورة تبني الابتكار في مختلف

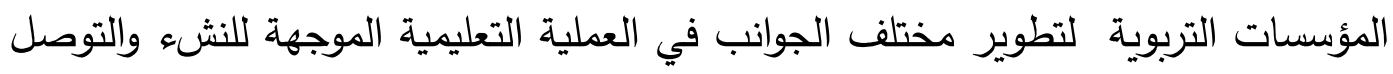

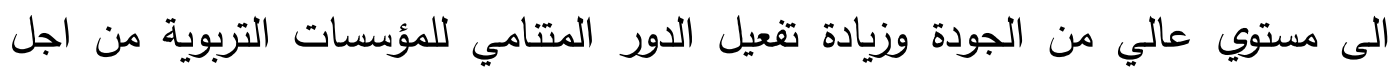
مواجهة التحديات المختلفة وتتمية مهارات الابتكار لدي تلك الفئات. وهذا ما اكدته دراسة ( Svensson \& other , 2019 ) حيث اسفرت نتائجها لاتهات على ان المنظمات التي تعتمد برامج مهنية واضحة الخطوات والاستراتيجيات ويجد بهات

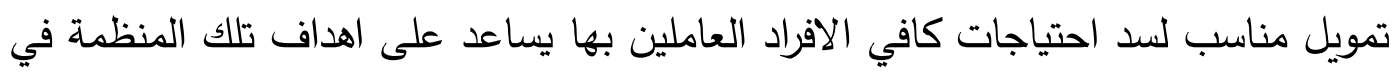
تتمية الابتكار لدى الفئات التى تستهدفها. 
وكذلك اكدت دراسة (ابو صالح، 2017) على العديد من النتائج كان اهمها ان

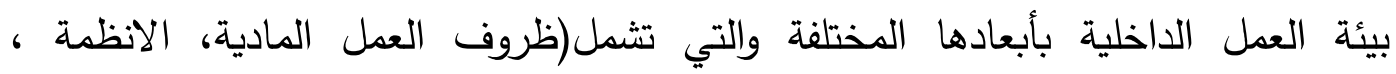
التعليمات، اللوائح، تكنولوجيا المعلومات، المشاركة في اتخاذ القرارات) تئثر على مستوي

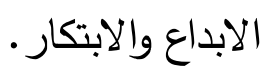

وبالرغم من وجود الأهداف والسياسات والاستراتيجيات الداعمة للابتكار للى الفئات

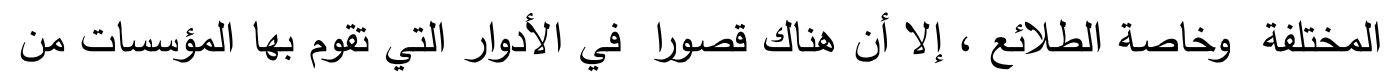

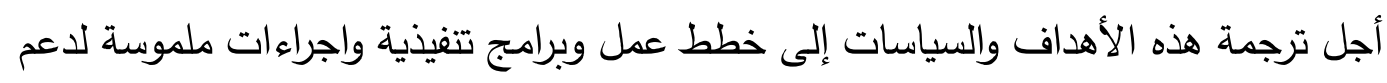

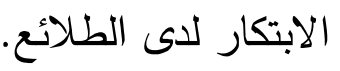

فقد أكدت دراسة (الكواري ، المناعي2013) علي أهمية تركيز الاخصائيين الاجتماعيين في مؤسسات رعاية الثباب علي تنفيذ السياسات والاجراءات والمبات المبادئ

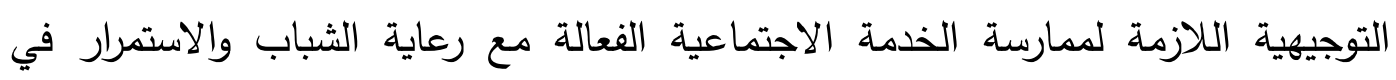
تحسين الخدمات المقدمة للثباب وفقا لسياسات و اجراءات مكتوبة لمتابعة ورصد عمليات البرامج.

وقد اشارت دراسة (2012 - Shelley \& Cairns ) إلى ضرورة تحديد برامج الرعاية المقدمة للشباب والأطفال طبقا للسياسات العامة المخطط لها من قبل الهبل المجتمع،

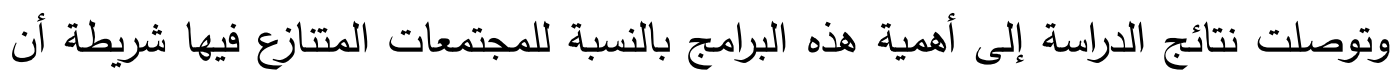

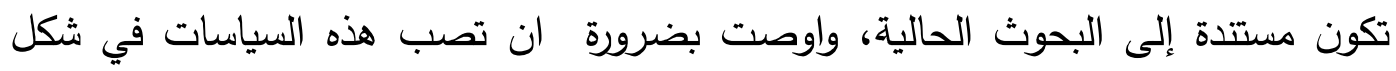

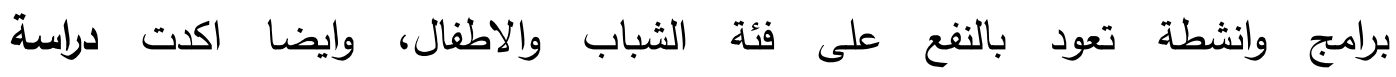
(G.walsh,2011)

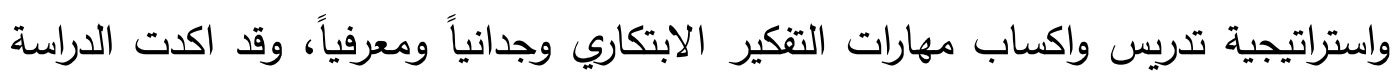

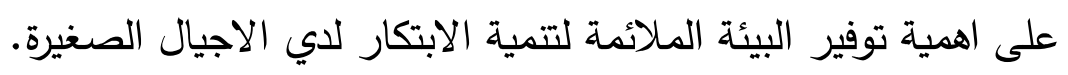
والخدمة الاجتماعية كمهنة إنسانية يمارسها متخصصون، بما لديها من وسائكائل لإيائل

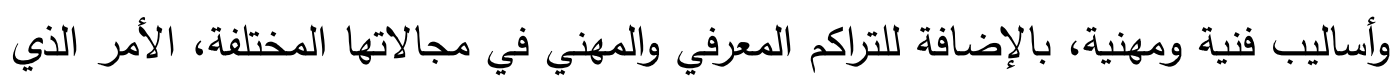

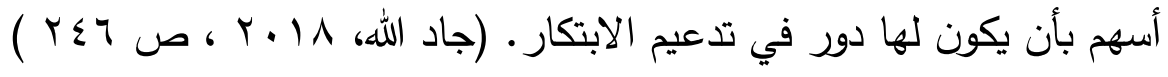

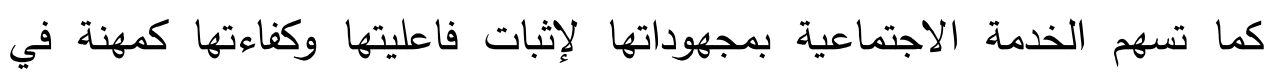

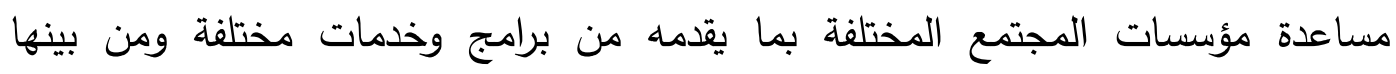

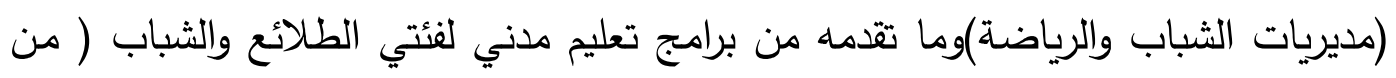


خلال ما تواجهها من تحديات ومعوقات والتي يتطلب أن يكون لكافة المهن دورا حيويا في

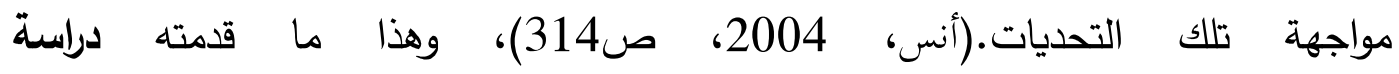
(عبدالحفيظ،2009) حيث هدفت الدراسة الى تقويم البرامج المقدمة للطلائع بمراكز الثباب

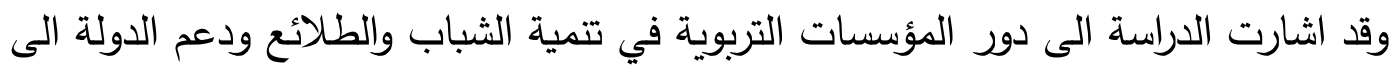
تلك المؤسسات من خلال دعم البرامج والانثطة الاجتماعية والعلمية والرياضية والانتاجية لتبنية

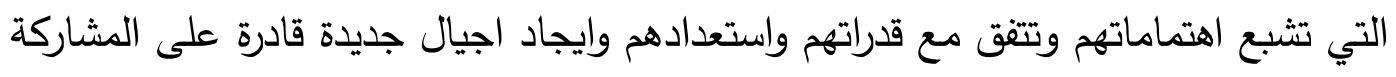
الايجابية.

كما يمكن للخدمة الاجتماعية أن تساهم في تقويم فعالية البرامج "كبرامج التعليم

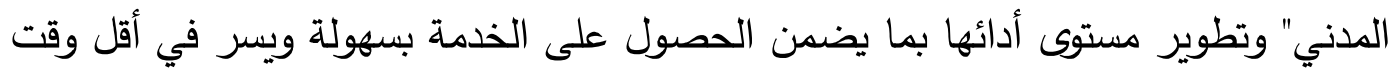

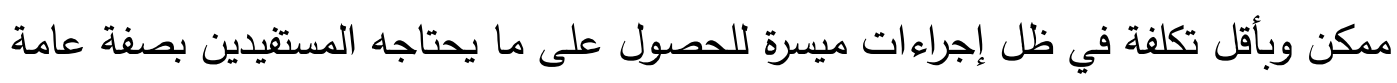

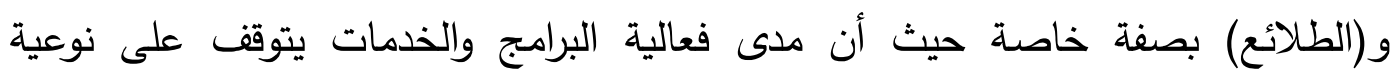
المستفيدين منها وأنواع المشكلات التي يعانون منها ونوعية ومستوى الخدمة المطلوبة وفي فئي

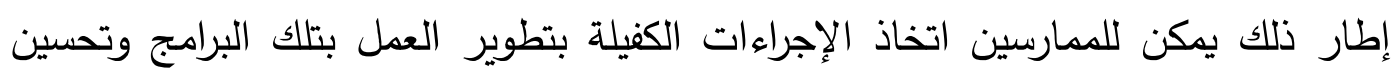

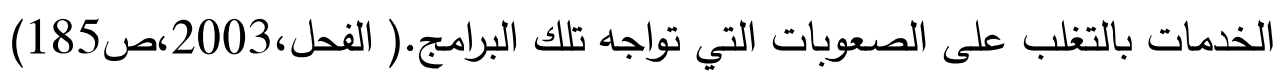

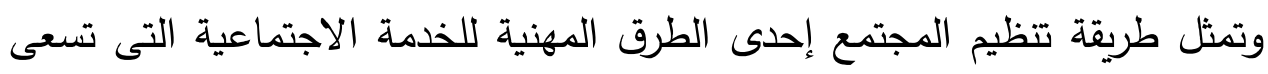

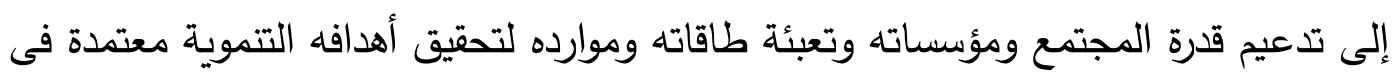

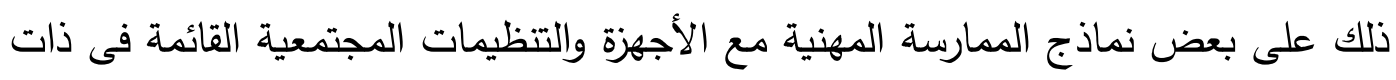

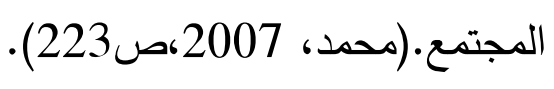
لذلك تبدو مسئولية طريقة تنظيم المجتمع كبيرة فى المجتمعات ومؤسساته حيث

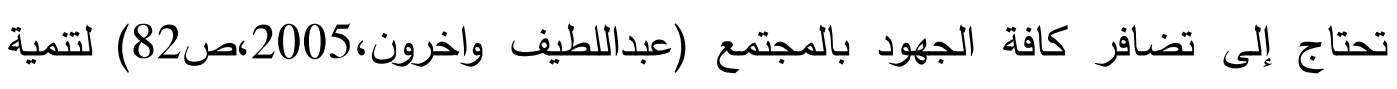
الابتكار لاي فئة الطلائع بمراكز الثباب، حيث تهدف طريقة تنظيم المجتمع إلى الاستفادة

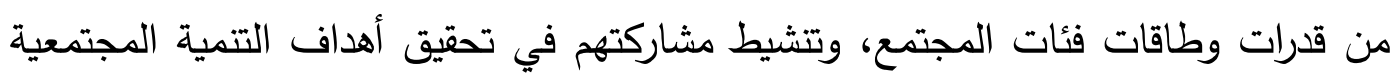

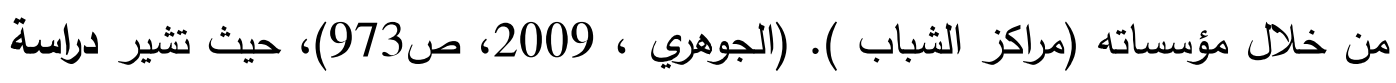

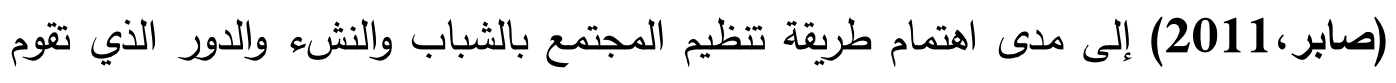

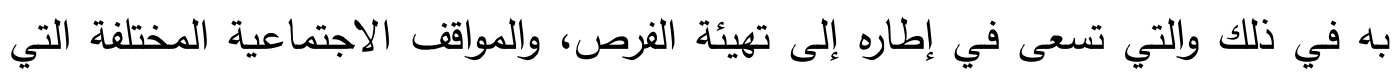

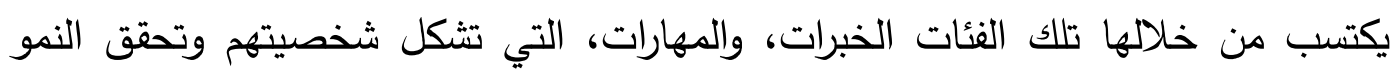
المتكامل لهم، وايضا أكدت دراسة (شعبان، 2010 ) بضرورة استخدام مهارات الممارسة الفيات 


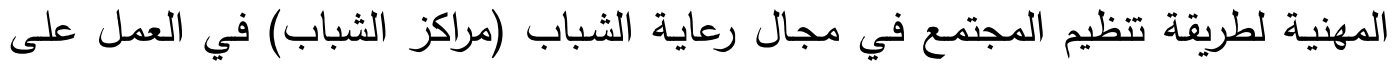

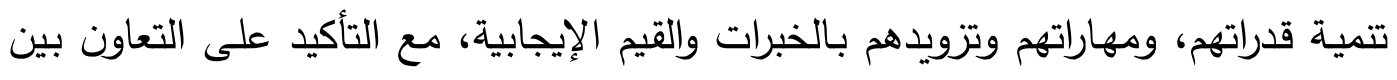

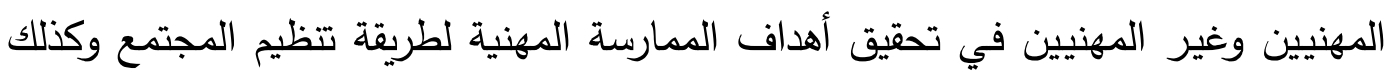
أهداف المؤسسات في هذا الثأن. وانطلاقاً من دور مهنة الخدمة الاجتماعية وطريقة تنظيم المجتمع في العمل مع فئة

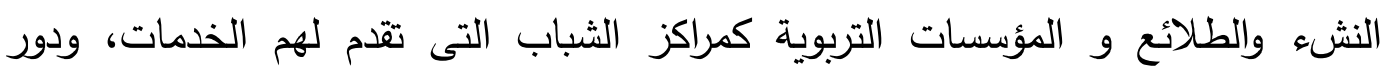
الطريقة في بناء البرامج والانشطة الدقدمة لتلك الفئة، واهمية التفكير الابتكاري ومهارته لدئي فئة الطلائع، وبناءا على نتائج الدراسات السابقة فقد تم تحديد مشكلة الدراسة في :

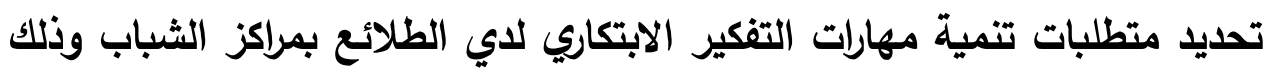

من منظور طريقة تنظيم المجتمع. ثانياً: اهمية الدراسية:

1- اهمية فئة الطلائع داخل المجتمع باعتبارهم نواة المجتمع واهمية إعدادهم بما يواكب

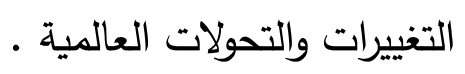

2- اتجاهات المجتمع ومؤسساته المختلفة الحكومية والمدنية الى تكثيف الاهتمام بفئة الطلائع وتمثل تلك الدراسة احد اشكال الاهتمام بتلك الفئه. 3- ضرورة الارتقاء بوظائف مراكز الثباب لكي تتبنى ادوار تربوية في دعم الابتكار لدي الدي الطلائع.

4- الحاجة الملحة في دعم الابتكار لدي فئات المجتمع المختلفة وخاصة الطلائع والتى

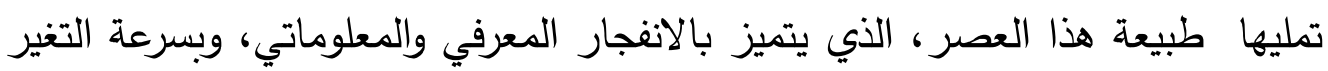
التكنولوجي والاقتصادي والثقافي. 5-تتبع اهمية الدراسة من اهمية قضية التتشئة الاجتماعية والفكرية بشكل عام ولفئة الطلائع بشكل خاص في ظل حركة المجتمع المصري نحو التغيير والاصلاح.

\section{ثالثً: اهداف الدراسة}

1- تحديد المتطلبات الادارية المرتبطة بتتمية مهارات التفكير الابتكاري لدي الطلائع بمراكز الثباب. 2- تحديد المنطلبات الخاصة بالبرامج المرتبطة بتنمية مهارات التفكير الابتكاري لدي الطلائع بمراكز الثباب. 


\section{مجلة كلية الخدمة الاجتماعية للار اسات و البحوث الاجتماعية - جامعة مـ}

3- تحديد المتطلبات التمويلية المرتبطة بتمية مهارات التنكير الابتكاري لدي الطلائع بمراكز الثباب.

4- تحديد المتطلبات التكنولوجية المرتبطة بتمية مهارات التفكير الابتكاري لدي الطلائع بمراكز الثباب.

5- تحديد الصعوبات التي تحد من تتمية مهارات التفكير الابتكاري لدي الطلائع بمراكز الثباب.

6- التوصل لرؤية مستقبلية من منظور طريقة تتظيم المجتمع لتتمية مهارات التتكير الابتكاري

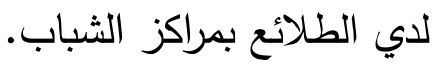

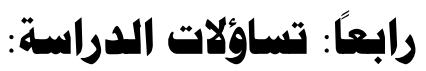

1- ما المتطلبات الادارية المرتبطة بتتمية مهارات التفكير الابتكاري لدي الطلائع بمراكز الثباب؟

2- ما المتطلبات الخاصة بالبرامج المرتبطة بتتمية مهارات التثكير الابتكاري لدي الطلائع بمراكز الشباب؟

3- ما المتطلبات التمويلية المرتبطة بتمية دهارات التفكير الابتكاري لدي الطلائع بمراكز

$$
\text { الثباب؟ }
$$

4- ما المتطلبات التكنولوجية المرتبطة بتمية مهارات التتكير الابتكاري لدي الطلائع بمراكز

$$
\text { الشباب؟ }
$$

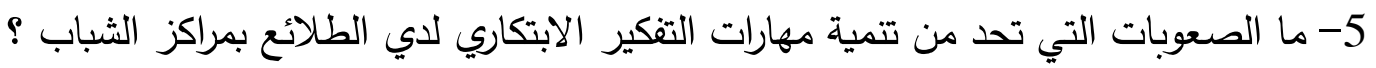

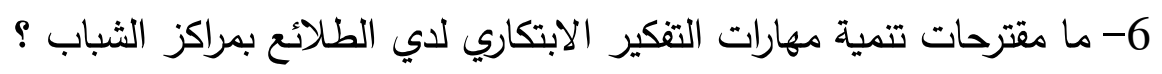

\section{خامساً: مفاهيم الدراسة:} تتناول الدراسة عدة مفاهيم تمثلت في الآتي: (أ)مفهوم المتطلبات:

المتطلب هو مرادف لمفهوم الحاجه فهي تحديد الموارد المتاحة التى يمكن استخدامها في الربط والتتسيق حتي يمكن تجنب الازدواجية والصراع والتنافس وايضا الرفاهية

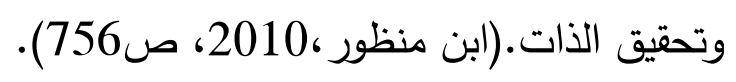

ويعرف المتطلب بانه شيء يستلزم وجوده أو شرط يجب توافره أو هو الثي الذي

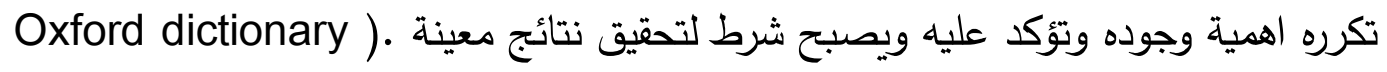




\section{مجلة كلية الخدمة الاجتماعية للار اسات و البحوث الاجتماعية - جامعة لمبرم}

ويعرف بانه الجانب الذي يجب توافره ويكون هناك حاجه لوجوده كشرط مطلوب .

(Webster dictionary ,1991,p1071))

والمتطلبات هي مجموعة الصفات والخصائص والعناصر التى تتجمع وتتألف معا

في الافراد او المؤسسات وفق ظروف مختلفة وتعد بمثابة سلوك ظاهري كما تمثل ركائز

في تحقيق الاهداف.(سلام، 200، صان

وتعرف المتطلبات اجرائيا في اطار تلك الدراسة بانها:

- مجموعة الجوانب التي يجب توافرها داخل مراكز الثباب من اجل اكساب الطلائع

مهارات التفكير الابتكاري.

- - تهدف تلك الجوانب الى تطوير اداء مراكز الثباب بما يساعده على تحقيق اهدافها التى من ضمنها تتمية مهارات التفكير الابتكاري لدي الطلائع

- - تسهم تلك الجوانب في تتمية مهارات الطلائع وخاصة في التفكير الابتكاري. - تضمن تلك الجوانب جوانب ادارية وجوانب تمويلية وجوانب تكنولوجية وجوانب خاصة بالبرامج التي تستهدف الطلائع.

(ب) مفهوم التفكير الابتكاري:

تعددت مفاهيم الابتكار تبعا لكل تخصص فكل تخصص يراه من زاويته فنهم من

يعرفه بانه ناتج محدد ومنهم من يراه مناخ مؤسسي او بيئي والبعض الاخر يراه على انه عملية تتضمن عدة مراحل في حين يختزله البعض في انه قدرة عقلية. فيعرفه البعض بانه ايجاد حل جديد او اصيل لمشكلة علمية او عملية او فنية او اجتماعية، أي ان الابتكار يعني رؤية الامور والمشكلات من زوايا جديدة بأن يفرغ عليها الشخص معني جديداً.(أديب،2003، ص 22)، كما يشير الابتكار الى القدرة على الربط

بين الافكار بأسلوب غير تقليدي وبشكل متوافق بينهما. (Robbins, S. P. , 2005,p404) كما يشار اليه بانه كل نشاط انساني يؤدي الى ناتج ابتكاري بفعل عوامل معينة تؤدي اليه، ويشار الى ناتجه بصفة الاصالة والقيمة والمغزي واستمرار الاثر وقد يكون هذا الناتج ادبيا او علميا.(موسي، الخطاب، 2004،صداب،

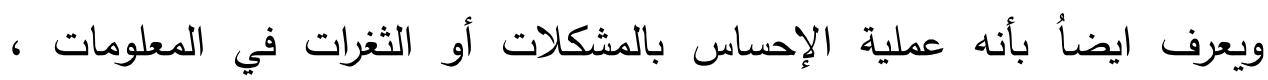
وصياغة الأفكار أو الفروض ، واختبار وتعديل هذه الفروض ، وايصال النتائج، وهذه العملية تقود إلى العديد من النتاجات المتتوعة اللفظية وغير اللفظية الحسية والمجردة، مع 
عدم إغفال بقية التعاريف، بحيث تتم مراعاة القدرات والسمات الابتكارية والناتج الابتكاري ،

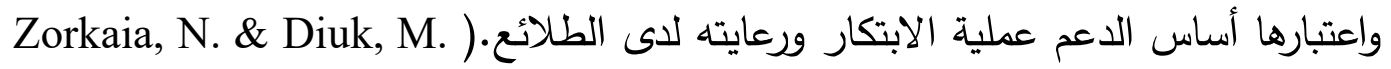
(,2004,p87

ويعرف الابتكار ايضا بانه الكل جديد يقوم به الانسان سوء كان ذلك في شكل

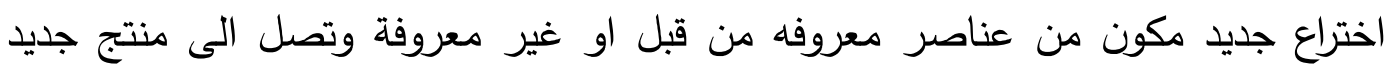

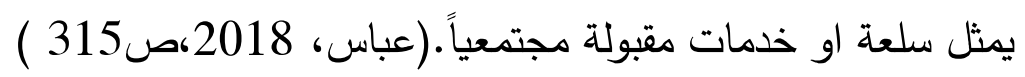

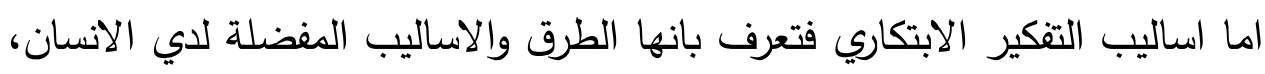

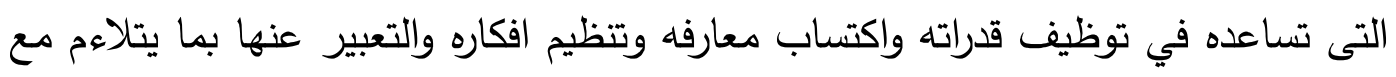
المهام والمواقف التى تواجهه، لذا يكون أسلوب التثكير الذي يستخدمه في مواقف التف الحياة

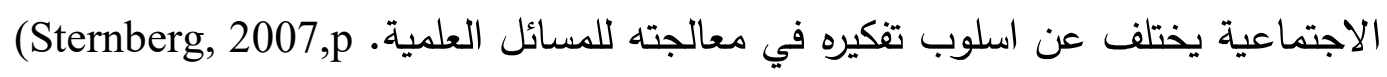

واما التفكير الابتكاري فانه يعرف بانه عملية عقلية معرفية تتصف بالطلاقة والمرونة والاصالة والحساسية للمشكلات وينتج عنه نواتج ابتكارية. ( Cano,F. \& Hewitt, ) E,2000, p413

فالتثكير الابتكارى جوهر التقدم العلمي والتكنولوجي باعتباره أرقي مستويات النشاط

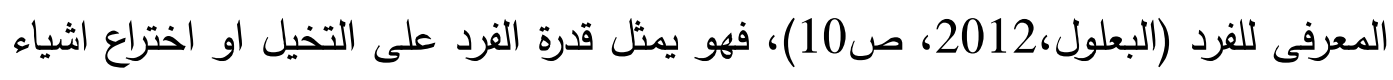

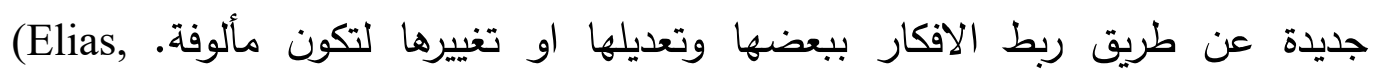
(2004,p108

ويعرف التفكير الابتكاري اجرائياً في اطار تلك الدراسة بانه: - - عملية عقلية معرفية يتمتع بها الطلائع. - يساعدهم في توظيف قدراتهم واكتساب معارف وتتظيم افكارهم والتعبير عنها بما يتلاءم

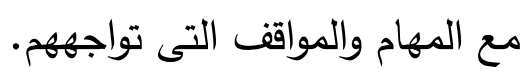
- يقودهم إلى التوصل للعديد من النتاجات المتتوعة اللفظية وغير اللفظية الحسية والمجردة. - له مجموعة من المهارات وهي الطلاقة والافاضة والحساسية للمشكلات، والاصالة والمرونة 


\section{سادسا: المنطلقات النظرية للدراسة:}

\section{(أ) نظرية التحكم العقلي الذاتي(لستيرنبرج):}

هي احد النظريات التى تنسر اسلوب التقكير للانسان وتسمي بنظرية نظرية التحكم العقلي الذاتي لستيرنبرج (Sternberg,s theory of Mental Self- Government) وقد اوضحت ان الاشخاص يكون لديهم العديد من الاساليب وليس اسلوبا واحدا فى لئي

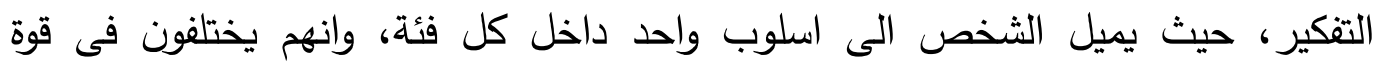
تفضيلهم ومرونتهم لأساليب التفكير ، ويخلطون بين ملائمة الاسلوب ومستويات القدرة لذلك الك الكي

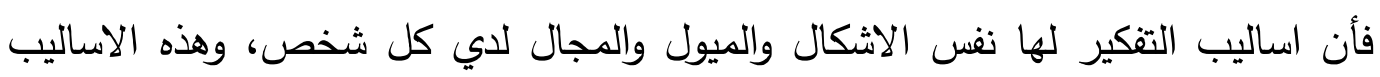

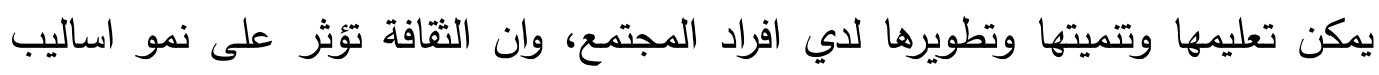

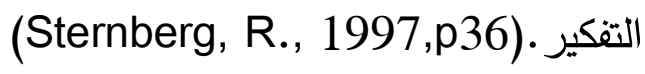
وتقوم نظرية التحكم العقلي الذاتي على ان اساليب التفكير تقسم الى ثلاثة مجموعات كما يلي:(Zhang, L. 2002,p331) - مجموعة تتضمن تتفيذ الاشياء بأبداع مما يذل على مستويات عليا معقدة من الجانب المعرفي وتثمل (المتحرر -الككمي0 الهرمي- العالمي -التشريعي).

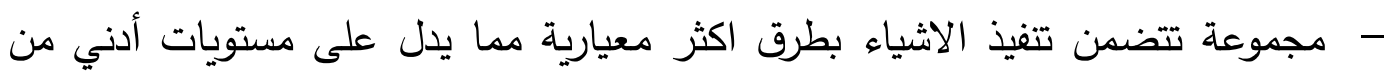
التعقيد المعرفي وتثمل (التتفيذي- المحلي- المحافظ -الملكي).

- مجموعة تشمل الاساليب التقليدية فى التفكير منها ( السطحي -الفوضوي- الداخلي).

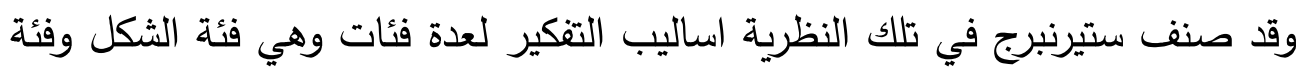
الوظيفة وفئة النزعة وفئة المجال وفئة المستوي وتثمل كل فئة على عدة اساليب للتنكير

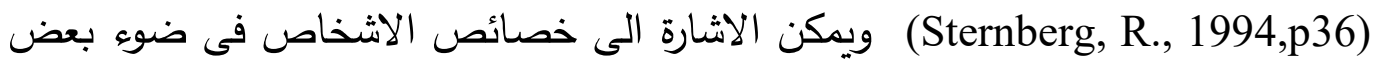

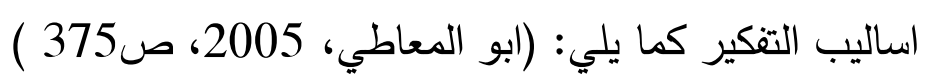

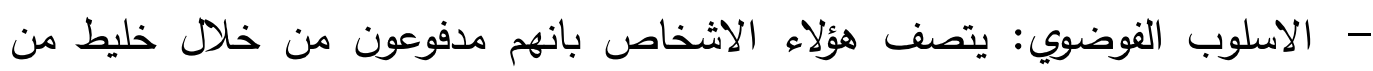

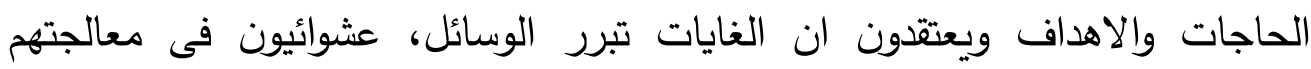
للمشكلات ، من الصعب تقسير الدوافع وراء سلوكهم.

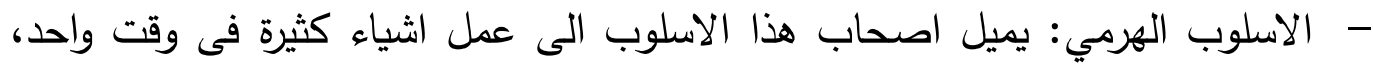

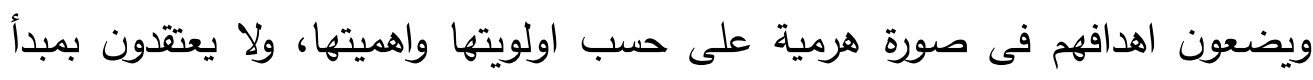


الغاية تبرر الوسيلة، مرنون ومنظمون جدا ومدركون للأولويات، ويتميزون بالواقعية والمنطقية فى تتاول المشكلات.

- الاسلوب الملكي: ويتصف هؤلاء الاشخاص بالتوجه نحو هدف واحد طوال الوقت

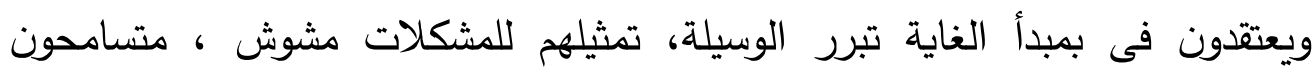
ومرنون، لديهم ادراك قليل نسبيا بالأولويات.

- الاسلوب الأقلي: يتصف هؤلاء الاشخاص باندفاعهم نحو اهداف متساوية الاهمية،

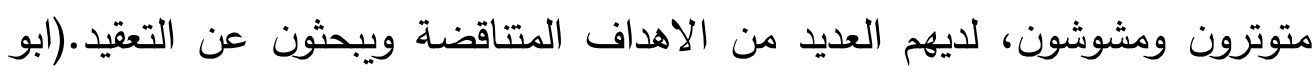

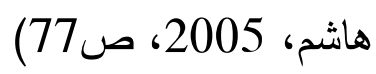
- الاسلوب التنفيذي: هذا الاسلوب يميز الاشخاص الذين يميلون لاتباع القواعد

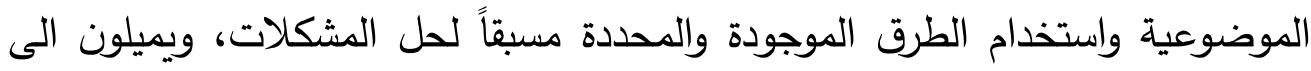
تطبيق القوانين وتتفيذها والتفكير بواقعية والموضوعية.

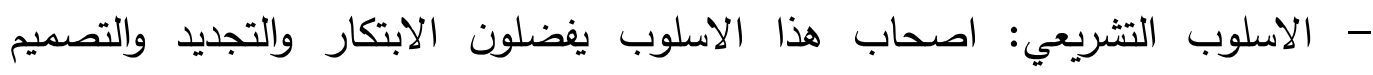
والتخطيط لحل المشكلات وعمل الاشياء بطريقتهم الخاصة، ويميلون لبناء النظام والمحتوي لكيفية حل المشكلة ويفضلون المهن التي تمكنهم من توظيف اسلوبهم. - الاسلوب الداخلي: اصحاب هذا الاسلوب يفضلون العمل بمفردهم منطوون ويكون

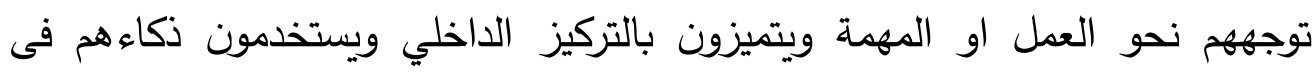

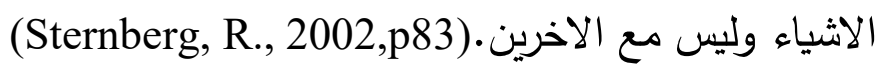

\section{(ب)- نموذج العمل مع مجتمع المنظمة:}

يهدف تلك النموذج الى التعامل المهني مع مكونات المنظمة المعنمة الاجتماعية ومجتمعها الذاتي لمساعدتها على خدمة فئتها بفاعلية متزايدة، ويقوم النموذج على فلسفة محددة وهي:

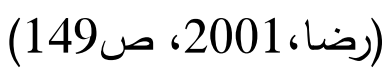

- - اهمية التعمق داخل المنظمة ودراستها وذلك للوقوف على النواحي السلبية والايجابية لها. - معالجة النواحي السلبية وتدعيم الجوانب الايجابية داخل المنظمة.

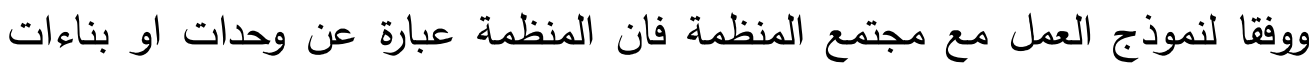

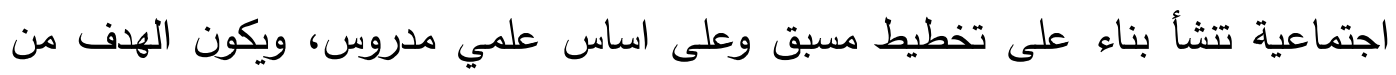

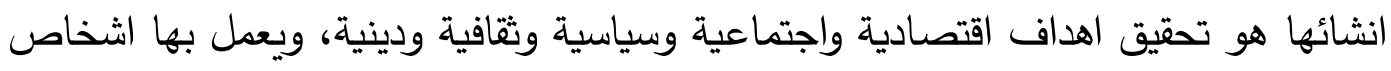
مهنيون واداريون يسعون لتحقيق تلك الاهداف، وتقوم على اساس التفاعل بين تلك العناصر 
المكونة لها وعلى اساس التفاعل مع المجتمع المحيط بها، وتتظم العلاقات بين افرادها وبين المجتمع من خلال مجموعة من اللوائح المكتوبة او المتعارف عليها كالقيم والعادات

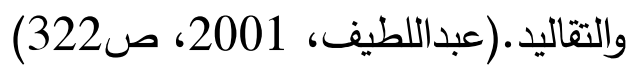

\section{ويعتمد النموذج العمل مع مجتمع المنظمة على مجموعة من العمليات الاجرائية اهمها:} - - المساهمة فى تطوير المنظمة ذاتها لزيادة فعالية تعاملها مع المجتمع والمستثيدين. - - المساهمة فى اقامة علاقات متوازية بين الجهاز الإداري والمهني بالمنظمة. - التعرف على اراء المستفيدين فيما يقدم لهم من خدمات. - - دراسة الصعوبات التي تواجه العمل مع المهني بالمنظمة والعمل على حلها. - ضمان تأثير سياسة المنظمة بآراء المهنيين و بنتائج عملية المحاسبية الاجتماعية.

- - دراسة احتياجات افراد المنظمة حتي تعمل المنظمة على المساعدة فى اشباعها. - التأثير فى عملية اتخاذ القرار بالمنظمة لصالح الاعضاء المكونين للمنظمة والمنتفعين

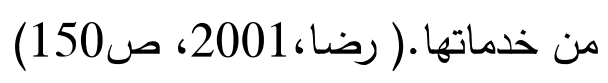

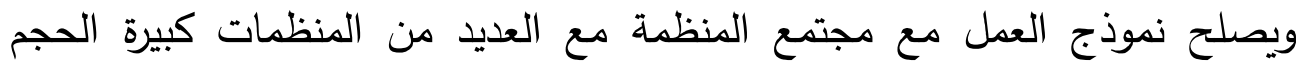

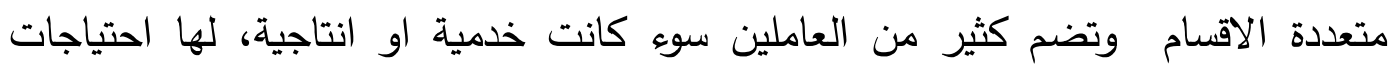

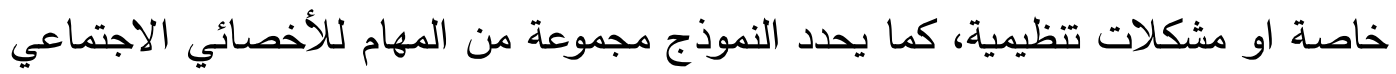

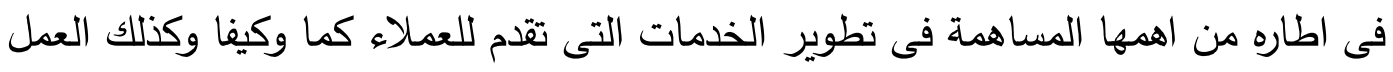
على توفير الظروف الملائمة داخل تلك المنظمة التى يعمل بها، وايضا ممارسة العديد من فن اهن

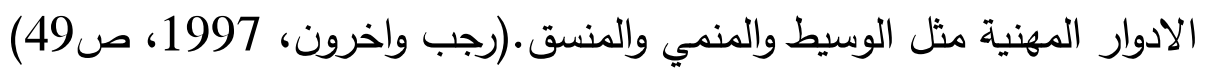

\section{سابعاً: الإطار النظري للدراسة:}

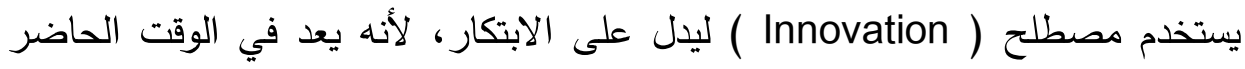

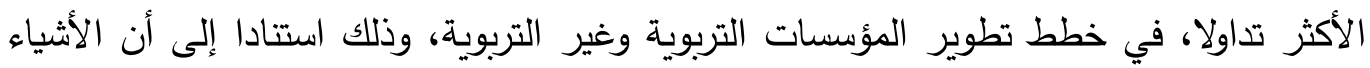

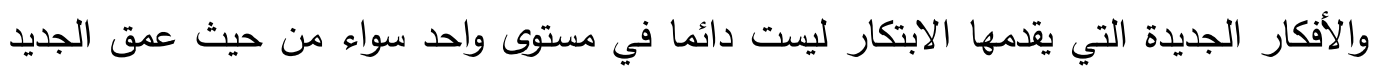

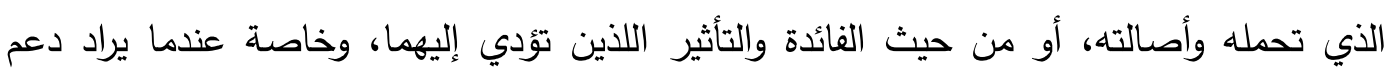
وتعزيز عمليات الابتكار لدى الطلائع.

ويمثل الإنتاج الابتكاري محصلة لمجموعة من العوامل التي تتصب على قدئ قدرة الفرد ، وتؤدي

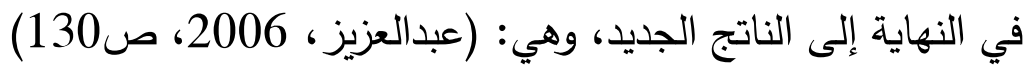

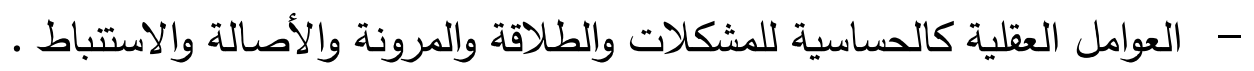
- العوامل الشخصية التي يتصف بها المبدع كالثقة بالنفس والاكتفاء الذاتي. 
- العوامل الدافعية كتحقيق الذات وهو أرقى دوافع الإنجاز للفرد .

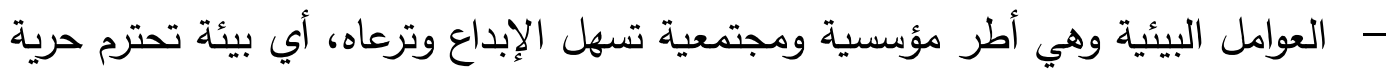

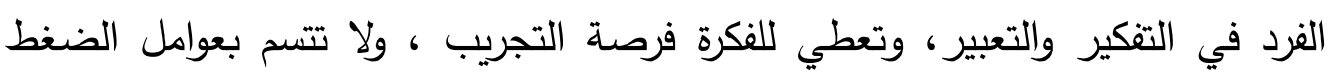

\section{مهارات التفكير الابتكاري: وفئ}

تتقسم مهارات التفكير الابتكاري الى عدة مهارات من اهمها:

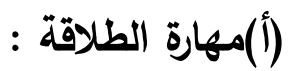

تعرف مهارة الطلاقة بأنها" قدرة الفرد على توليد عدد كبير من البدائل أو الأفكار أو

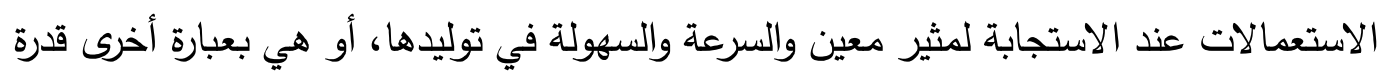

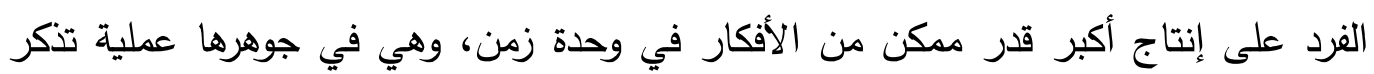

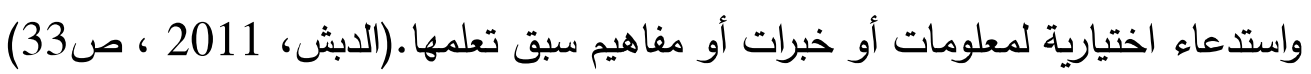
وتتضمن عملية الطلاقة الإبداعية القدرة على إنتاج أكبر عدد من الأفكار الإبداعية

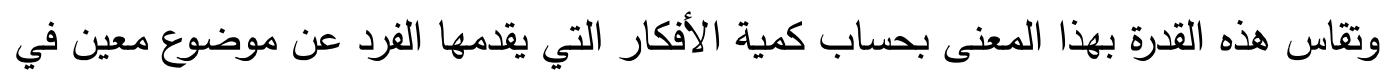

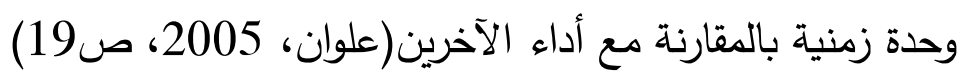

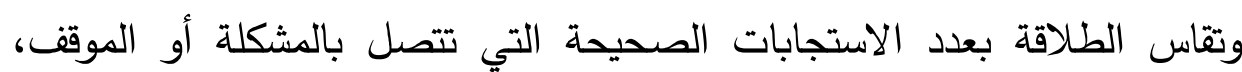

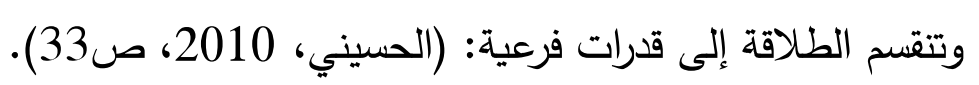

- الطلاقة اللفظية: وتعني سرعة تفكير الفرد في إعطاء الكلمات وتوليدها. - - -اقة المعاني : وتعني التفكير السريع في كلمات متصلة تتاسب موقفًا معينًا أو القدرة على إنتاج أكبر عدد ممكن من الألفاظ وفق شروط معينة من حيث المعات المعنى. - الطلاقة التعبيرية :أي التفكير السريع في كلمات متصلة تلاسب موقفا معينًا وصياغة

$$
\text { أفكارفي عبارات مفيدة. }
$$

- طلاقة الأفكار: وهي استدعاء عدد كبير من الأفكار في زمن محدد.وهناك فرق بين

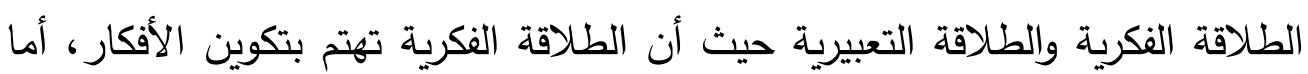
الطلاقة التعبيرية فهي تهتم بصياغة هذه الأفكار في ألفاظ.

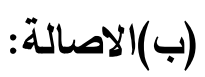

تعد الاصالة عنصرا اساسياً فى التفكير الابتكاري حيث تقوم على انتاج افكار جديدة او

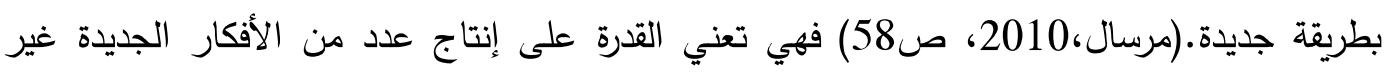




\section{مجلة كلية الخدمة الاجتماعية للار اسات و البحوث الاجتماعية - جامعة لمبرم}

Wilson. R. F. الثائعة والمدهثة والنادرة ، أو تقديم ما هو غير مألوف ، أو النفاذ لما وراء الواضح. $(, 2007, p 437)$

وتعرف مهارة الأصالة بأنها "الاتيان بأفكار جديدة ومتفردة ونادرة وغير مكرة ولا تكون مرتبطة بأفكار سابقة فهي تعكس القدرة على النفاذ إلى ما وراء الواضح أو المباشر والمألوف من الأفكار والتي تعني التفكير في أفكار وحلول مختلفة بعيدة عن المألوف والثائع من كمية الاستجابات التي تشير إلى ارتباطات غير مباشرة.(الزيات، 2009، صن5) (ج) المرونة: وتعني القدرة على تعميم الافكار او الحلول وتحويلها الى افكار مناسبة

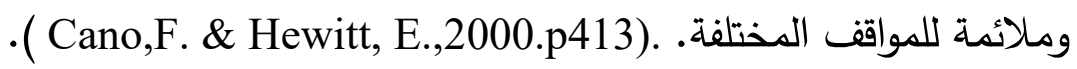
فالمرونة تعني كسر الجمود الذهني الذي يحيط بالأفكار القديمة، وهذا بدوره يقود الى تغيير الاتجاهات والميول، حيث يتم تعديل السلوك والعقل البشر بشكل تجعله بيئة صالحة تسمح للمعلومات ان تتشكل فى انماط مختلفة (القلا، 2006، صلفي4)، فهي القدرة على انتاج انواع مختلفة من الافكار وتحويل التفكير من مدخل الى اخر واستخدام مجموعة من الاستراتيجيات المختلفة التي تتاسب الموقف الجديد.(ريان، 2006، ص218) وهنالك شكلان للمرونة هما: المرونة التكيفية وهي القدرة على تغيير الوجهة الذهنية التي ينظر من خلالها إلى حل المشكلة المحددة، المرونة التلقائية وهي القدرة على سرعة إنتاج أكبر عدد من الأفكار المختلفة التي ترتبط بموقف معين.(الدبش، إن، 2011، ص34) الحساسية للمشكلات:

ويقصد بها الوعي بوجود مشكلات او حاجات او عناصر ضعف فى البيئة او الموقف، ويعني ذلك ان الافراد اسرع من غيرهم فى ملاحظة المشكلة والتحقق من وجودها

$$
\text { فى المواقف. (الطيطي، 2011، صان }
$$

كما تعني قدرة الغرد على رؤية المشكلات فى الاشياء والعادات او النظم ورؤية جوانب النقص والعيب فيها، وتوقع ما يمكن ان يترتب علي ممارستها وهذه المكونات ان تكون Ngaik. الافكار مناسبة وملائمة لمقتضيات البيئة والواقع بعيدة عن العشوائية. $(, 2005, \mathrm{p} 46)$.

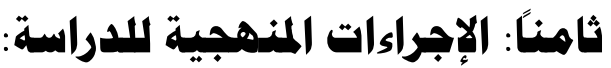

(أ) نوع الدراسة ومنهجها:

تنتمي هذه الدراسة الى نمط الدراسات الوصفية باعتبارها من انسب الدراسات ملائمة لموضوع الدراسة، كما تعتمد الدراسة على منهج المسح الثامل بنوعيه كمنهج علمي لها . 
(ب) أدوات الدراسة:

اعتمدت الدراسة على استخدام أداتين للإجابة على تساؤلاتها وهما: استمارة استبيان

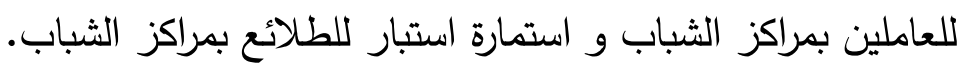

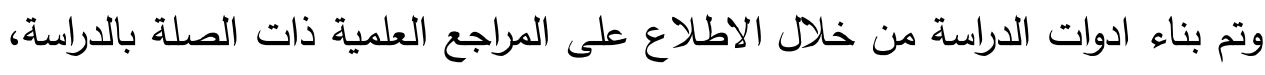

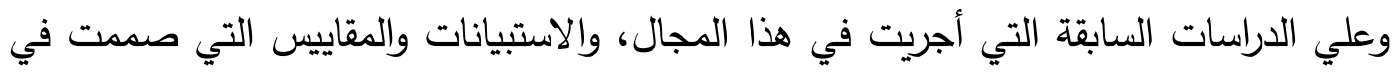
البحوث والدراسات السابقة المتعلقة بتغيرات الدراسة (مهارات التنكير الابتكاري - الطلائع -

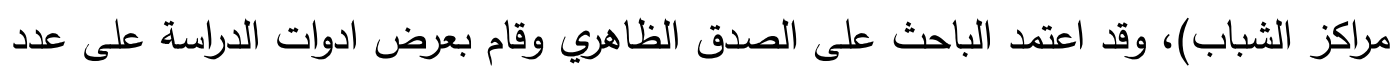

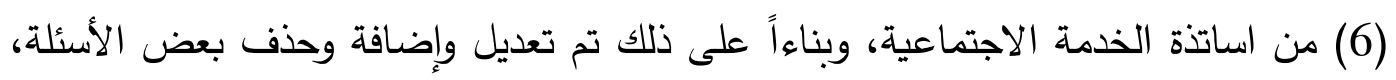

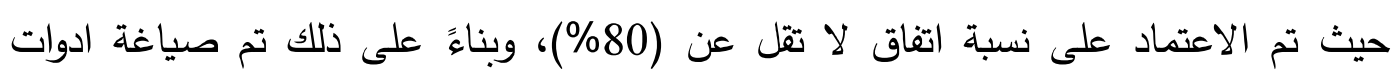

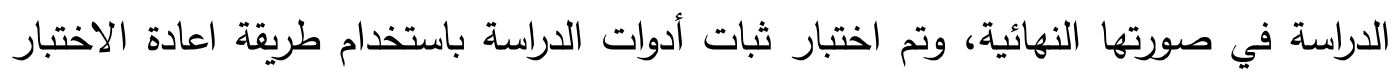

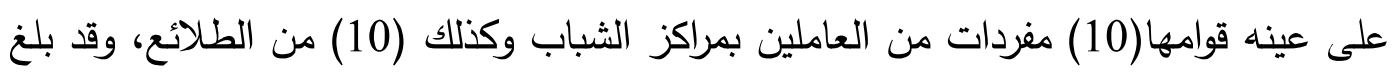

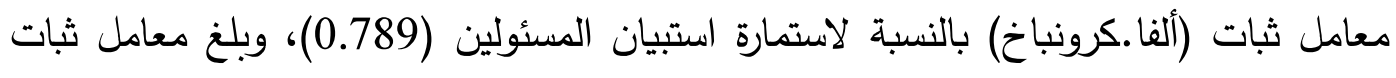

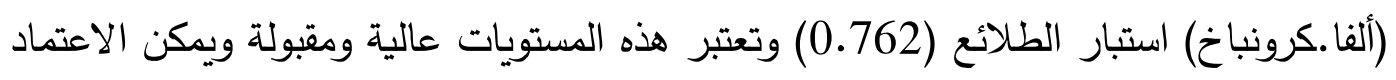
على النتائج التي تتوصل إليها الأدوات. (ج) مجالات الاراسة: 1-المجال المكاني.

تحدد المجال المكاني للدراسة في مراكز الثباب الواقعة في نطاق ادارة منطقة الزيتون

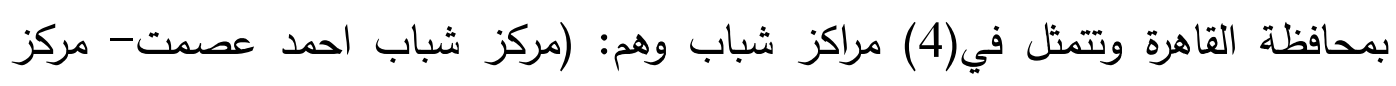
شباب عين شمس- مركز شباب عزبة النخل- نادي المطرية)، وتم اختيار منطقة الزيتون

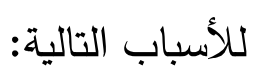

- - كثرة اعداد الطلائع وتتوعهم داخل مراكز الثباب بتلك المنطقة.

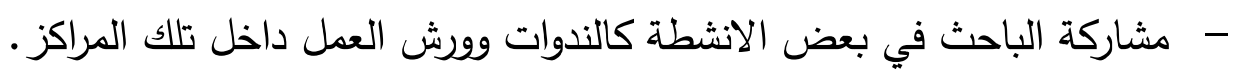
- تقبل تلك المراكز بإجراء الدراسة بها.

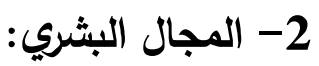
- - حصر شامل للعاملين بمراكز الثباب السابق ذكرها وعددهم (47) مسئول.

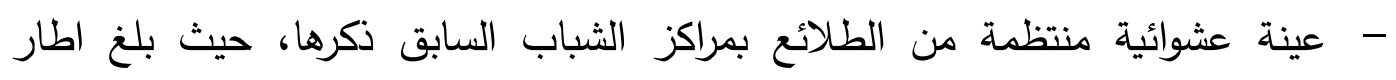
المعاينة للطلائع (1446) مفردة وبتطبيق معادلة الحجم الامثل باستخدام معادلة لستيفن ثامبسون بلغ عدد العينة (303) مفردة. 
وتم اختيار اطار المعاينة للطلائع طبقا للشروط التالية: - ان يكون لديه عضويه فعاله داخل مركز الشباب. - ان لا يقل عمره عن 10 اعوام لايه عضوبه فعاله دان

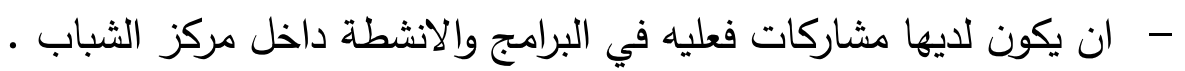
جدول (1) يوضع اعداد مجتمع الاراسة في لئل

\begin{tabular}{|c|c|c|c|c|}
\hline حجم العينة & اطلار المعاينة & العاملين & المكان & م \\
\hline 97 & 462 & 14 & مركز شباب احمد عصمت & 1 \\
\hline 73 & 348 & 13 & مركز شباب عين شمس & 2 \\
\hline 87 & 417 & 11 & مركز شباب عزبة النخل & 3 \\
\hline 46 & 219 & 9 & نادي المطرية & 4 \\
\hline 303 & 1446 & 47 & مجـــ & \\
\hline
\end{tabular}

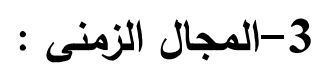

يتضمن المجال الزمنى للدراسة فترة جمع المعلومات من مفردات الدراسة خلال الفترة

$$
\text { (2020/11/7) إلى (2020/12/9). }
$$

(د) اساليب التحليل الاحصائي:

تم الحكم على مستوى منطلبات تتمية مهارات التفكير الابتكاري لدي الطلائع بمراكز

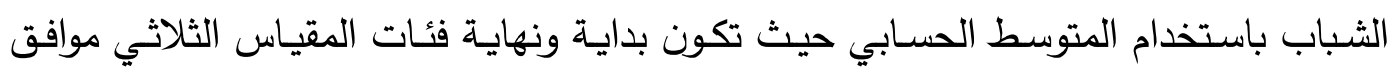

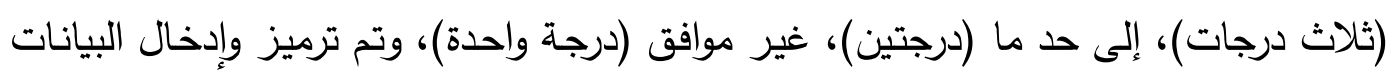

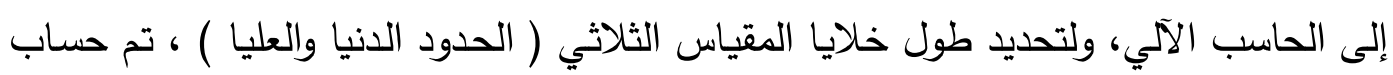

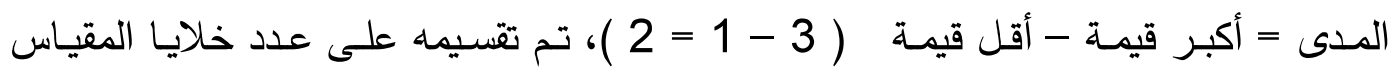

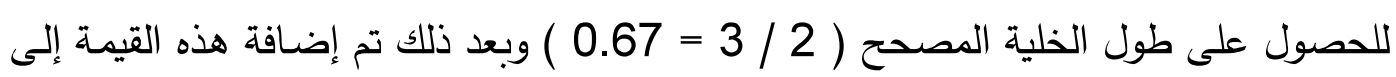
أقل قيمة في المقياس أو بداية المقياس وهى الواحد الصحيح وذلك لتحديد الحد الأعلى لهذه الخلية.

\begin{tabular}{|c|c|}
\hline 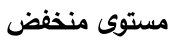 & إذا تراوحت قيمة المتوسط للعبارة أو البعد بين 1 - 1.67 \\
\hline مستوى متوسط & إذا تراوحت قيمة المتوسط للعبارة أو البعد بين أكثر من 1.67 - 2.34 \\
\hline مستوى مرتفع & إذا تراوحت قيمة المتوسط للعبارة أو البعد بين أكثر من 2.34 : 3 \\
\hline
\end{tabular}

جدول (2) يوضح مستوي المتوسطات الحسابية

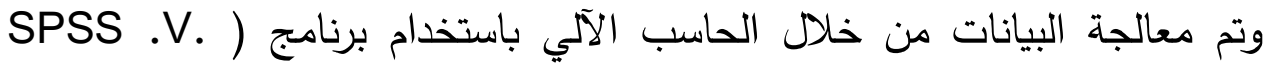
24.0) الحزم الإحصائية للعلوم الاجتماعية، وقد طبقت الأساليب الإحصائية التالية: 
التكرارات والنسب المئوية، المتوسط الحسابي، الانحراف المعياري، المدى، معامل ثبات (المب،

$$
\text { ألفا ـ كرونباخ ). }
$$

تاسعًا: نتائج الدراسة الميدانية:

$$
\text { (أ) وصف مجتمع الدراسة }
$$

جدول (3) يوضح وصف مجتمع الدراسة من العاملين بمر اكز الثباب (ن= 47)

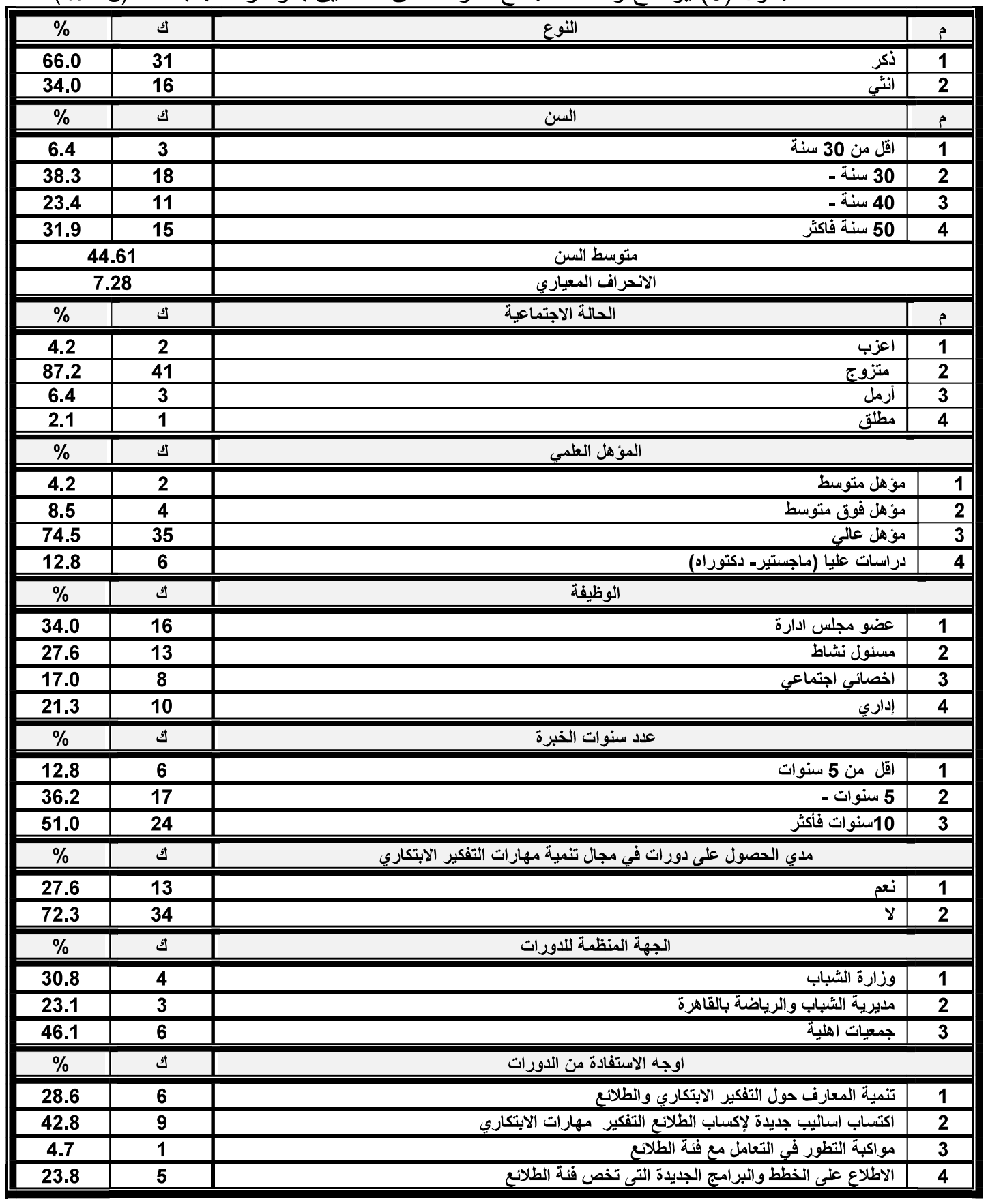

يوضح الجدول السابق وصف مجتمع الدراسة من العاملين بمراكز الثباب: 
- - بالنسبة للنوع جاء نسبة الذكور (66\%) بينما جاء نسبة الاناث (444\%).

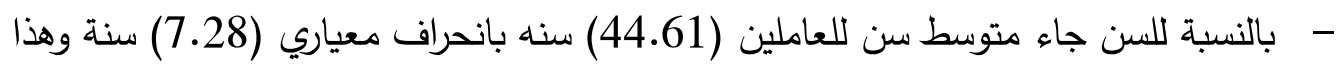

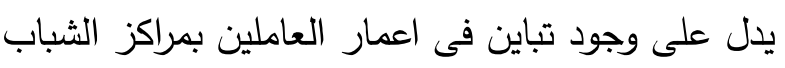

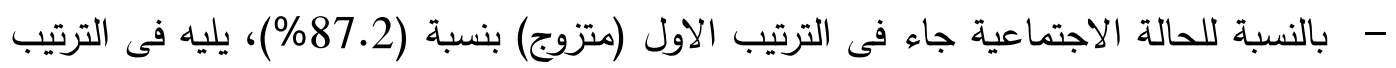

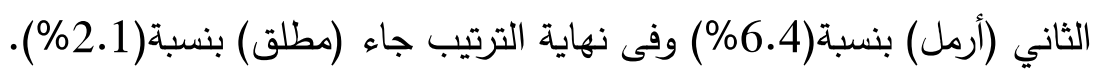

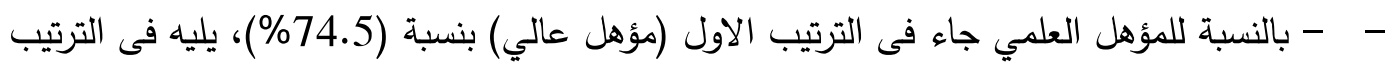
الثاني (دراسات عليا (ماجستير - دكتوراه) ) بنسبة(12.8\%) وفى نهاية الترتيب جاء (مؤهل متوسط) بنسبة(4.2\%).

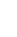

النسبة للوظيفة جاء فى الترتيب الاول (عضو مجلس ادارة) بنسبة (34\%)، يليه فى الترتيب الثاني

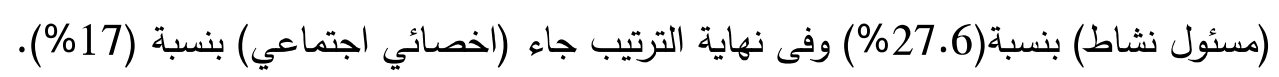

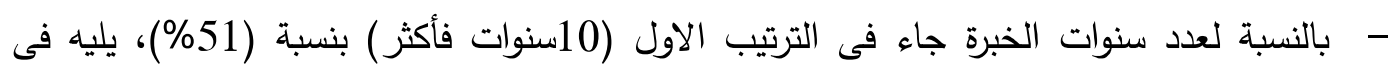
الترتيب الثاني (5 سنوات -) بنسبة(36.2\%) وفى نهاية الترتيب جاء (اقل من 5 سنوات) بنسبة(12.8\%). - بالنسبة لمدي الحصول على دورات تدريبية في مجال تتمية مهارات التنكير الابتكاري جاءت

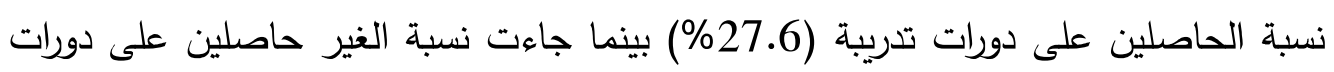

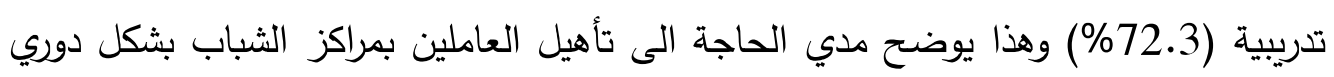
حتي يستطيعوا اكساب الطلائع مهارات التنكير الابتكاري.

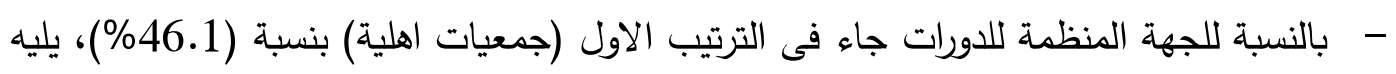
فى الترتيب الثاني (وزارة الشباب) بنسبة(30.8\%) وفى نهاية الترتيب جاء (مديرية الثباب التباب والرياضة بالقاهرة) بنسبة(23.1\%).

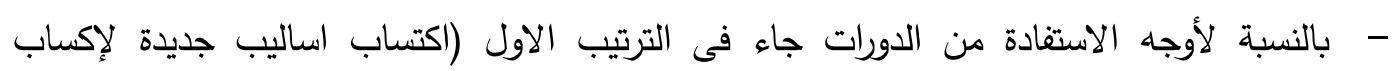

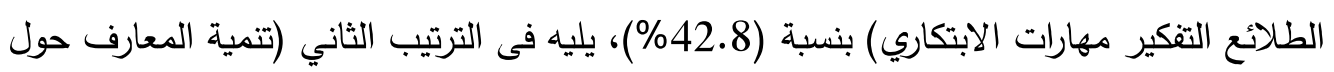

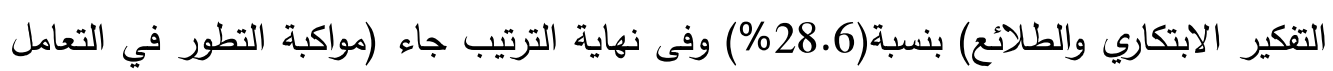

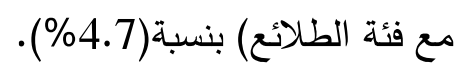


$(303=0)$ جدول (4) يوضح وصف مجتمع الدر اسة من الطلائع

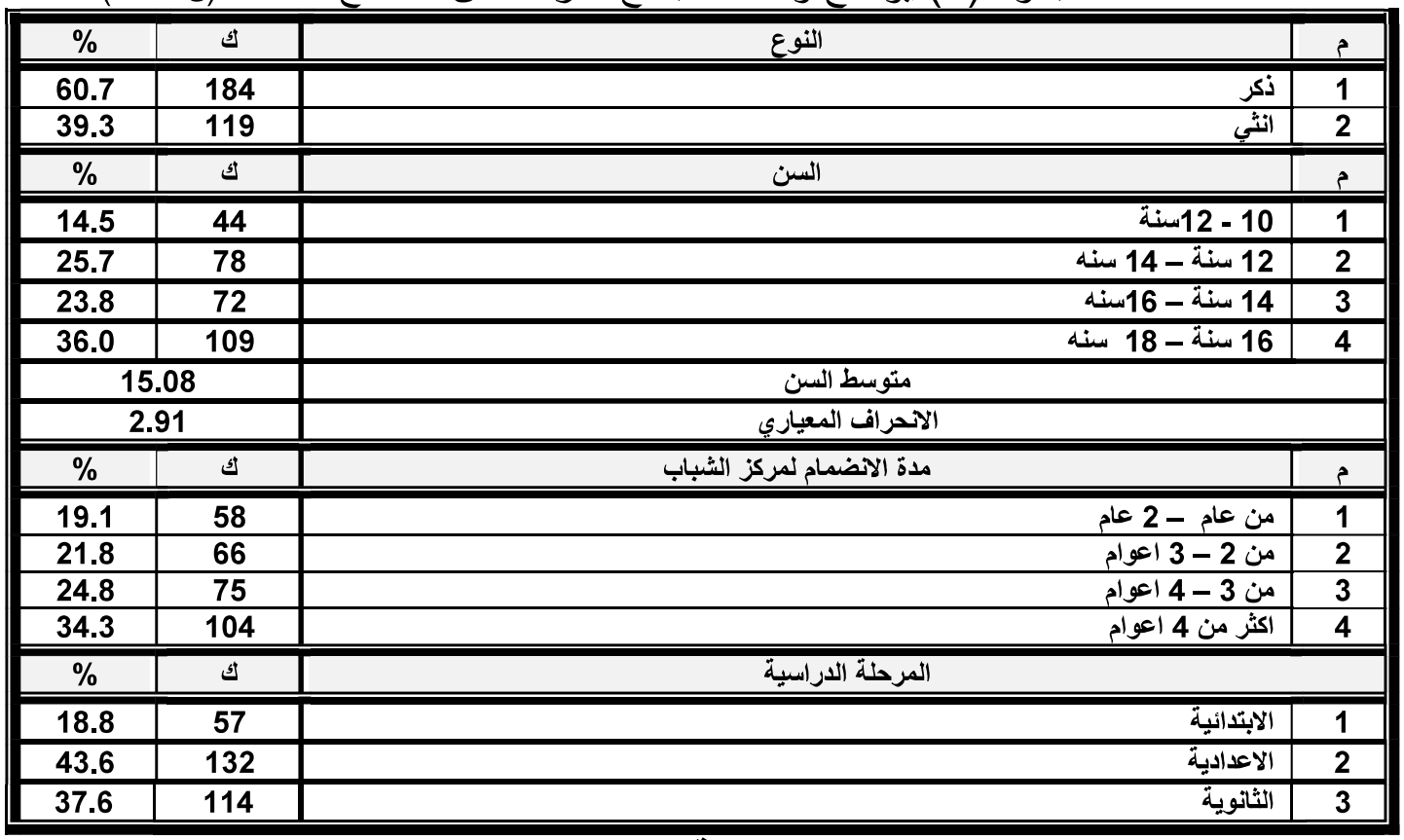

يوضح الجدول السابق وصف مجتمع الاراسة من الطلائع بمراكز الشباب:-

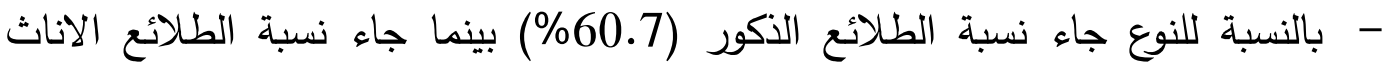
.$(\% 39.3)$

- - بالنسبة للسن جاء متوسط سن الطلائع (15.8) سنه بانحراف معياري (2.91) سنة . - بالنسبة لمدة الانضمام لمركز الشباب جاء فى الترتيب الاول (اكثر من 4 اعوام) بنسبة (34.3\%)، يليه فى الترتيب الثاني (من 3 - 4 اعوام) بنسبة(24.8\%) وفى نهاية

$$
\text { الترتيب جاء (من عام - } 2 \text { عام) بنسبة(19.1\%). }
$$

- بالنسبة للمرحلة الدراسية جاء فى الترتيب الاول (الاعدادية) بنسبة (43.6\%)، يليه فى الترتيب الثاني (الثانوية) بنسبة(37.6\%) وفى نهاية الترتيب جاء الابتدائية) بنسبة(18.8\%). 
(ب): اهم مهارات التفكير الابتكاري التى يحتاجها الطلائع

جدول (5) يوضح مهارات التفكير الابتكاري التى يحتاجها الطلائع

\begin{tabular}{|c|c|c|c|c|c|c|c|c|c|c|c|c|c|}
\hline \multicolumn{3}{|c|}{ ن = (303) } & \multicolumn{3}{|r|}{ الطلائع } & \multicolumn{2}{|c|}{ ن= (47) } & \multicolumn{4}{|c|}{ |العاملين بمراكز الثباب } & \multirow{2}{*}{ العبارة العبر } & \multirow[b]{2}{*}{ م } \\
\hline | تلترتيب & الالحمراف & المتوسطى & موافير & إلي حد ما & موافق & | الترتيب| & |الاتحراف| & |المتوسطى & موافير & إلي حد & |موافق | - مواث | & & \\
\hline 3 & 0.669 & 2.53 & 30 & 81 & 192 & 1 & 0.586 & 2.70 & 3 & 8 & 36 & مهارة الطلاقة & 1 \\
\hline 2 & 0.725 & 2.55 & 42 & 52 & 209 & 4 & 0.599 & 2.65 & 3 & 10 & 34 & للمشكارة الحساسية & 2 \\
\hline 5 & 0.726 & 2.46 & 42 & 78 & 183 & 6 & 0.718 & 2.51 & 6 & 11 & 30 & مهارة المرونة & 3 \\
\hline 4 & 0.665 & 2.47 & 29 & 101 & 173 & 7 & 0.770 & 2.40 & 8 & 12 & 27 & مهارة الافاضة & 4 \\
\hline 6 & 0.777 & 2.44 & 54 & 61 & 188 & 2 & 0.555 & 2.68 & 2 & 11 & 34 & مهارة التحليل & 5 \\
\hline 7 & 0.722 & 2.33 & 45 & 111 & 147 & 5 & 0.677 & 2.61 & 5 & 8 & 34 & مهارة الاصعالة & 6 \\
\hline 1 & 0.578 & 2.64 & 16 & 75 & 212 & 3 & 0.478 & 2.65 & - & 16 & 31 & مهارة التواصل الفعال & 7 \\
\hline \multicolumn{6}{|c|}{2.49 مرتفع } & \multicolumn{6}{|c|}{2.60 مرتفع } & \multicolumn{2}{|l|}{ ككل المتوسط الوزنى للبعد } \\
\hline \multicolumn{6}{|c|}{0.327} & \multicolumn{6}{|c|}{0.331} & \multicolumn{2}{|l|}{ الانحراف المعياري } \\
\hline
\end{tabular}

يوضح الجدول السابق:

مستوي مهارات التقكير الابتكاري التى يحتاجها الطلائع كما

يحددها العاملين حيث بلغ المتوسط الوزني (2.60) وهو مستوي (مرتفع) ومؤشرات ذلك وفقاً لترتيب المتوسط لوزني: جاء في الترتيب الأول (مهارة الطلاقة) بمتوسط وزني (2.70)، يليها في الترتيب الثاني (مهارة التحليل) بمتوسط وزني (2.68)، وجاء في نهاية الترتيب (مهارة الافاضة) بمتوسط وزني (2.40). - مستوي مهارات التفكير الابتكاري التى يحتاجها الطلائع كما يحدها الطلائع حيث بلغ المتوسط الوزني (2.49) وهو مستوي (مرتفع) ومؤشرات ذلك وفقاً لترتيب المتوسط لوزني: جاء في الترتيب الأول (مهارة التواصل الفعال) بمتوسط وزني (2.64)، يليها في الترتيب الثاني (مهارة الحساسية للمشكلات) بمتوسط وزني (2.55)، وجاء في نهاية الترتيب (مهارة الاصالة) بمتوسط وزني (2.33). واتفق ذلك مع ما ذكره ( قطامي، 2001، ص217) ان الامم المتقدمة أولت العملية التعليمية وكيفية تتمية أساليب التفكير لدي ابنائها جل اهتمام وتتاولها الباحثون بالدراسة من مختلف جوانبها انطلاقاً من المردود التكنولوجي والحضاري للابتكار . (ب): المتطلبات الادارية المرتبطة بتنمية مهارات التفكير الابتكاري لاي الطلائع بمراكز 
جدول (6) يوضح المتطلبات الادارية المرتبطة بتنمية مهارات التفكير الابتكاري لدي الطلائع بمراكز الثباب

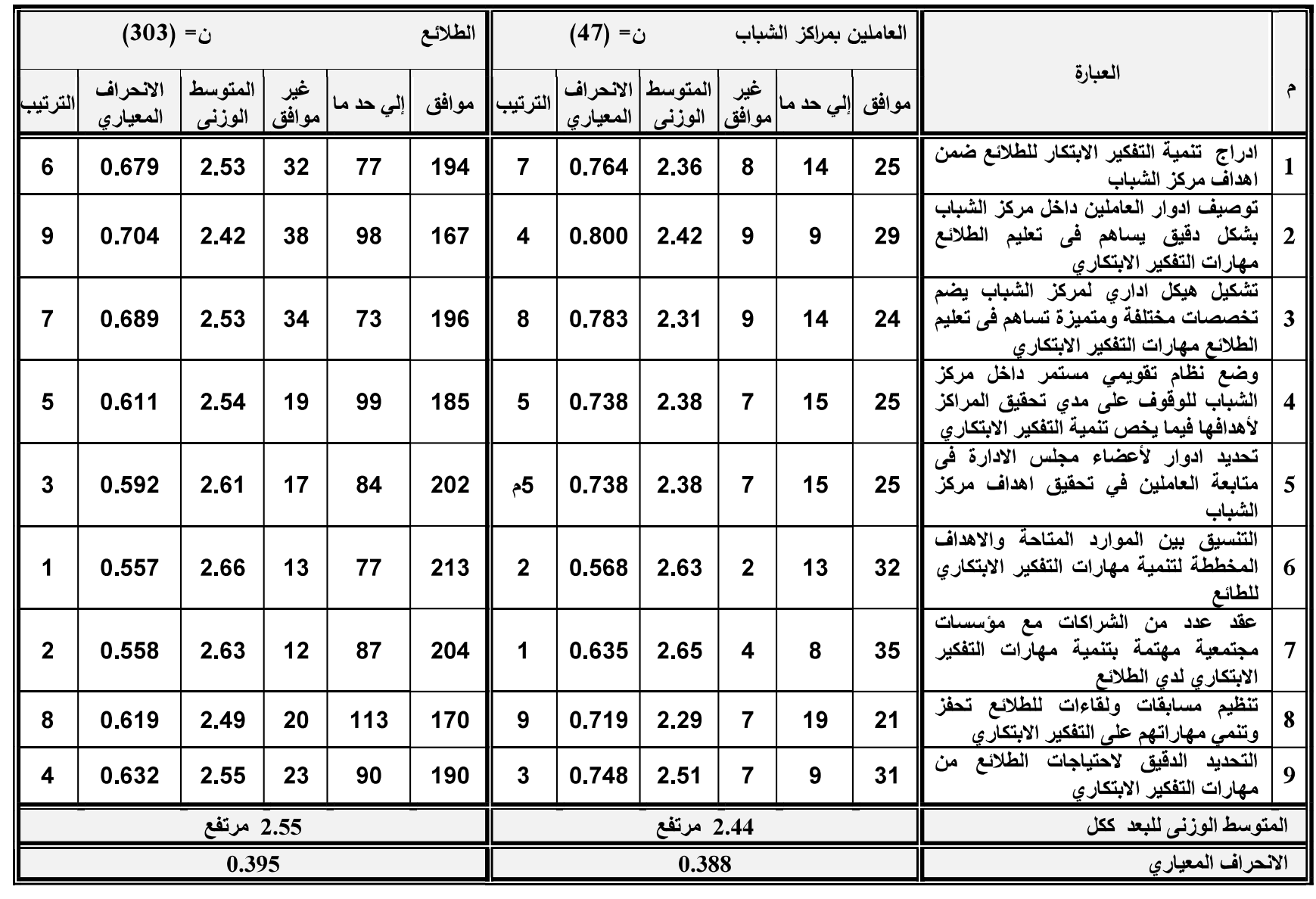

يوضح الجدول السابق:

مستوي المتطلبات الادارية المرتبطة بتمية مهارات التفكير

الابتكاري لدي الطلائع بمراكز الشباب كما يحدها العاملين حيث بلغ المتوسط الوزني

(2.44) وهو مستوي (مرتفع) ومؤشرات ذلك وفقاً لترتيب المتوسط لوزني: جاء في

الترتيب الأول (عقد عدد من الشراكات مع مؤسسات مجتمعية مهتمة بتنمية مهارات

التقكير الابتكاري لدي الطلائع) بمتوسط وزني (2.63)، يليها في الترتيب الثاني

(التتسيق بين الموارد المتاحة والاهداف المخططة لتمية مهارات التفكير الابتكاري

للطائع) بمتوسط وزني (2.63)، وجاء في نهاية الترتيب (تظيلم مسابقات ولقاءات

للطلائع تحفز وتتمي مهاراتهم على التفكير الابتكاري) بمتوسط وزني (2.29).

واتقق ذلك مع ما اكدته دراسة ( Svensson \& other , 2019 حيث اسفرت

نتائجها على ان المنظمات التي تعتمد برامج مهنية واضحة الخطوات والاستراتيجيات ويجد 
بها تمويل مناسب لسد احتياجات كافى الافراد العاملين بها يساعد على اهداف تلك المنظمة في تتمية الابتكار لدى الفئات التى تستهدفها. - مستوي المتطلبات الادارية المرتبطة بتمية مهارات التفكير الابتكاري لدي الطلائع بمراكز الشباب كما يحددها الطلائع حيث بلغ المتوسط الوزني (2.55) وهو مستوي (مرتفع) ومؤشرات ذلك وفقاً لترتيب المتوسط لوزني: جاء في الترتيب الأول (التتسيق بين الموارد المتاحة والاهداف المخططة لتمية مهارات التفكير الابتكاري للطائع) بمتوسط وزني (2.66)، يليها في الترتيب الثاني (عقد عدد من الشراكات مع مؤسسات مجتمعية مهتمة بتتمية مهارات التفكير الابتكاري لدي الطلائع) بمتوسط وزني (2.65)، وجاء في نهاية الترتيب (توصيف ادوار العاملين داخل مركز الشباب بشكل دقيق يساهم فى تعليم الطلائع مهارات التفكير الابتكاري) بمتوسط وزني (2.42)، وايضا اكدت دراسة (ابو صالح، 2017) على العديد من النتائج كان اهمها ان بيئة العمل الداخلية بابعادها المختلفة والتى تشمل(ظروف العمل المادية، الانظمة ، التعليمات، اللوائح، تكنولوجيا المعلومات، المشاركة في اتخاذ القرارات) تؤثر على مستوي الابداع والابتكار . (ج): المتطلبات الخاصة بالبرامج المرتبطة بتنمية مهارات التفكير الابتكاري لاي الطلائع بمراكز الشباب جدول (7) يوضتح المتطلبات الخاصة بالبرامج المرتبطة بتمية مهارات التفكير الابتكاري لدي الطلائع بمراكز الشباب

\begin{tabular}{|c|c|c|c|c|c|c|c|c|c|c|c|c|c|}
\hline \multicolumn{3}{|c|}{ ن = } & \multicolumn{3}{|r|}{ 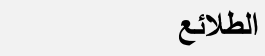 } & \multicolumn{2}{|c|}{ ن =ن } & \multicolumn{4}{|c|}{ العاملين بمراكز الشباب } & \multirow[b]{2}{*}{ 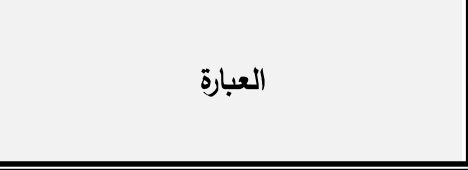 } & \multirow[b]{2}{*}{ P } \\
\hline لترتيب & المعياري & |المتوسطى & غوافير & إلي حد ما & موافق & |الترتيب|| & المعياري & |المتوسطى & |موافير & إلي حد & |موافق & & \\
\hline 2 & 0.647 & 2.60 & 27 & 67 & 209 & 5 & 0.654 & 2.52 & 4 & 14 & 29 & 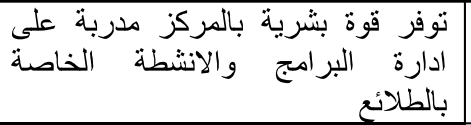 & 1 \\
\hline 1 & 0.655 & 2.61 & 29 & 59 & 215 & 4 & 0.677 & 2.61 & 5 & 8 & 34 & 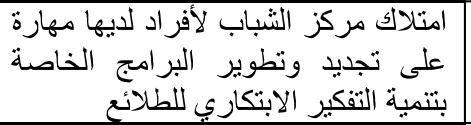 & 2 \\
\hline 5 & 0.698 & 2.45 & 36 & 92 & 175 & 3 & 0.573 & 2.61 & 2 & 14 & 31 & 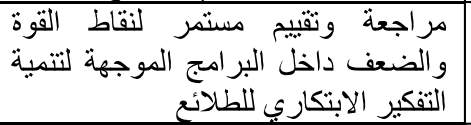 & 3 \\
\hline 7 & 0.689 & 2.41 & 35 & 107 & 161 & 7 & 0.683 & 2.42 & 5 & 17 & 25 & 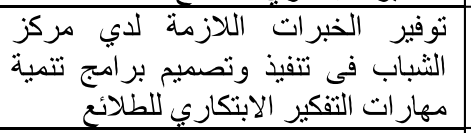 & 4 \\
\hline 6 & 0.728 & 2.42 & 43 & 87 & 173 & 2 & 0.640 & 2.63 & 4 & 9 & 34 & 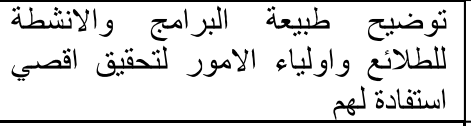 & 5 \\
\hline 8 & 0.764 & 2.39 & 52 & 79 & 172 & 1 & 0.615 & 2.72 & 4 & 5 & 38 & | دراسة الصعوبات التى تواجه تنفيذ & 6 \\
\hline
\end{tabular}




\section{مجلة كلية الخدمة الاجتماعية للار اسات و البحوث الاجتماعية - جامعة لمبرم}

\begin{tabular}{|c|c|c|c|c|c|c|c|c|c|c|c|c|c|}
\hline \multicolumn{3}{|c|}{ ن = } & \multicolumn{3}{|r|}{ الطلائع } & \multicolumn{2}{|c|}{ ن } & \multicolumn{4}{|c|}{ العاملين بمراكز الثباب } & \multirow{2}{*}{ 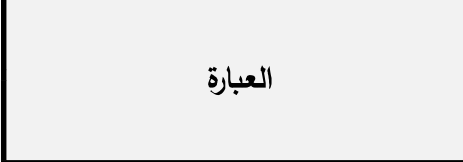 } & \multirow[b]{2}{*}{ r } \\
\hline لترتيب & الانحراف & |المتوسطى & غوافير & إلي حد ما & موافق & الترتيب & المبياري الان & |المتتوسطى & 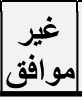 & إلي حا & موافق & & \\
\hline & & & & & & & & & & & & برامج تتمية مهارات التفكير الابتكاري & \\
\hline 4 & 0.712 & 2.53 & 39 & 64 & 200 & 8 & 0.798 & 2.40 & 9 & 10 & 28 & 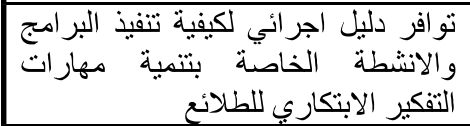 & 7 \\
\hline 2 & 0.647 & 2.60 & 27 & 67 & 209 & 6 & 0.748 & 2.48 & 7 & 10 & 30 & برامج تتمية بالتفوكير الابتكاري المهنية فلى تصئعيم & 8 \\
\hline \multicolumn{6}{|c|}{ 2.50 مرتفع } & \multicolumn{6}{|c|}{ 2.56 مرتفع } & \multicolumn{2}{|c|}{ المتوسط الوزنى للبعد ككل } \\
\hline \multicolumn{6}{|c|}{0.426} & \multicolumn{6}{|c|}{0.373} & \multicolumn{2}{|c|}{ الاتحراف المعياري } \\
\hline
\end{tabular}

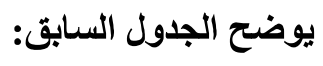

مستوي المتطلبات الخاصة بالبرامج المرتبطة بتمية مهارات

التفكير الابتكاري لدي الطلائع بمراكز الشباب كما يحدها العاملين حيث بلغ المتوسط بها بهاب الوزني (2.56) وهو مستوي (مرتفع) ومؤشرات ذلك وفقاً لترتيب المتوسط لوزني: جاء في الترتيب الأول (دراسة الصعوبات التى تواجه تتفيذ برامج تتمية مهارات التفكير الابتكاري) بمتوسط وزني (2.42)، يليها في الترتيب الثاني (توضيح طبيعة البرامج والانثطة للطلائع واولياء الامور لتحقيق اقصي استفادة لهم) بمتوسط وزني (2.63)، وجاء في نهاية الترتيب (توافر دليل اجرائي لكيفية تتفيذ البرامج والانشطة الخاصة بتتمية

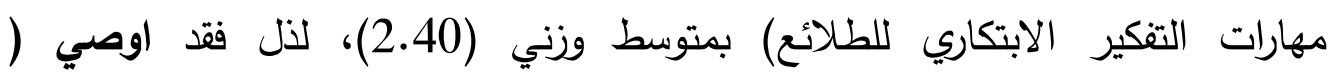
ب) بضرورة تبني الابتكار في مختلف المؤسسات التربوية لتطوير مختلف الجوانب في العملية التعليمية الموجهة للنشء والتوصل الى مستوي عالى من الجودة وزيادة تفعيل الدور المتنامي للمؤسسات التربوية من اجل مواجهة التحديات المختلفة وتتمية مهارات الابتكار لدي تلك الفئات. مستوي المتطلبات الخاصة بالبرامج المرتبطة بتمية مهارات التفكير الابتكاري لدي الطلائع بمراكز الثباب كما يحدها الطلائع حيث بلغ المتوسط الوزني (2.50) وهو مستوي (مرتفع) ومؤشرات ذلك وفقاً لترتيب المتوسط لوزني: جاء في الترتيب الأول (امتلاك مركز الشباب لأفراد لديها مهارة على تجديد وتطوير البرامج الخاصة بتتمية التفكير الابتكاري للطلأع) بمتوسط وزني (2.61)، يليها في الترتيب الثاني كلا من (الاستعانة بالمؤسسات المهنية فى تصميم برامج تتمية التفكير الابتكاري للطلائع) و (توفر قوة بشرية بالمركز مدربة على ادارة البرامج والانشطة الخاصة 
بالطلائع) بمتوسط وزني (2.60)، وجاء في نهاية الترتيب (دراسة الصعوبات التى تواجه تتفيذ برامج تتمية مهارات التفكير الابتكاري) بمتوسط وزني (2.39)، واتثق نتائج الجدول مع ما اوضحته دراسة (عزت, 2004) طبيعة وواقع البرامج التي تقدم للشباب والنشء من خلال مراكز الشباب و التى هدفت الى التعرف على المشكلات والمعوقات التي تعوق تنفيذ البرامج الترويجية للشباب، وأوصت الدراسة بأنه لابد أن تتضمن خطة مراكز الثباب برامج تتناسب مع احتياجات وقدرات الثباب والنشء، وضرورة إعداد أخصائيين اجتماعيين للعمل في مراكز الشباب والأندية الرياضية. ودعم مراكز الشباب بالقيادات المؤهلة علمياً. الطلائع بمراكز المتطبات التمويلية المرتبطة بتنمية مهارات التفكير الابتكاري لدي جدول (8) يوضح المتطلبات التمويلية المرتبطة بتنمية مهارات التنكير الابتكاري لدي الطلائع بمراكز الثباب

\begin{tabular}{|c|c|c|c|c|c|c|c|c|c|c|c|c|c|}
\hline \multicolumn{3}{|c|}{ ن = (303) } & \multicolumn{3}{|r|}{ الطلائع } & \multicolumn{2}{|c|}{ ن = (47) } & \multicolumn{4}{|c|}{ |العاملين بمراكز الثباب } & \multirow{2}{*}{ العبارة } & \multirow[b]{2}{*}{ p } \\
\hline لترتيب & الانحراف & |المتوسطى & غوير & مـ & موافق & الترتيب & 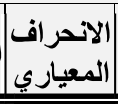 & |المتوسطى & مو غير & إلي حد & |موافق & & \\
\hline 6 & 0.699 & 2.50 & 36 & 80 & 187 & 4 & 0.716 & 2.55 & 6 & 9 & 32 & 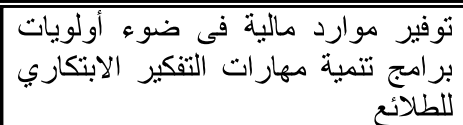 & 1 \\
\hline 7 & 0.722 & 2.49 & 41 & 71 & 191 & 8 & 0.795 & 2.38 & 9 & 11 & 27 & 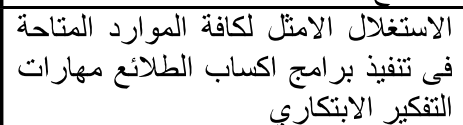 & 2 \\
\hline 2 & 0.642 & 2.56 & 25 & 83 & 195 & 7 & 0.655 & 2.51 & 4 & 15 & 28 & 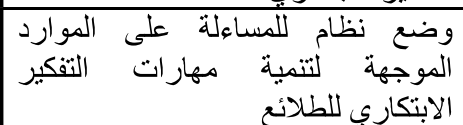 & 3 \\
\hline 3 & 0.696 & 2.56 & 36 & 61 & 209 & 5 & 0.716 & 2.55 & 6 & 9 & 32 & 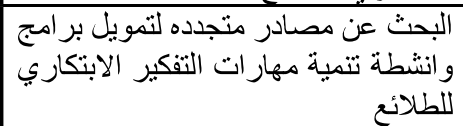 & 4 \\
\hline 1 & 0.670 & 2.58 & 31 & 64 & 208 & 2 & 0.605 & 2.63 & 3 & 11 & 33 & لأفكار هم الابتكارية وجائز الابداعية للطائع كدوافز & 5 \\
\hline 4 & 0.731 & 2.52 & 43 & 59 & 201 & 3 & 0.680 & 2.59 & 5 & 9 & 33 & 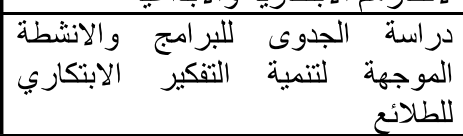 & 6 \\
\hline 8 & 0.755 & 2.43 & 49 & 74 & 180 & 6 & 0.621 & 2.51 & 3 & 17 & 27 & 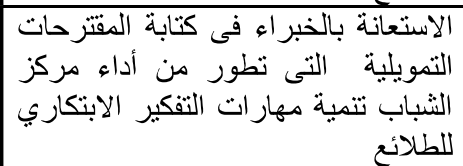 & 7 \\
\hline 5 & 0.731 & 2.51 & 43 & 62 & 198 & 1 & 0.668 & 2.65 & 5 & 6 & 36 & 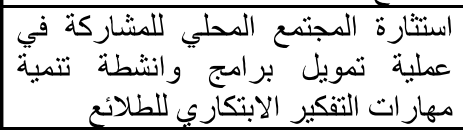 & 8 \\
\hline
\end{tabular}


مجلة كلية الخدمة الاجتماعية للار اسات و البحوث الاجتماعية - جامعة ميتي

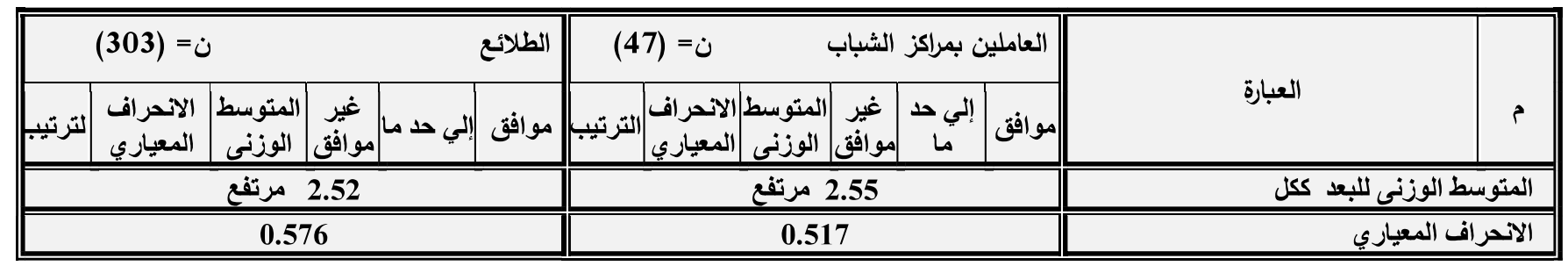

يوضح الجدول السابق:

مستوي المتطلبات التمويلية المرتبطة بتتمية مهارات التفكير

الابتكاري لدي الطلائع كما يحددها العاملين حيث بلغ المتوسط الوزني (2.55) وهو

مستوي (مرتفع) ومؤشرات ذلك وفقاً لترتيب المتوسط لوزني: جاء في الترتيب الأول

(استثارة المجتمع المحلي للمشاركة في عملية تمويل برامج وانشطة تتمية مهارات التفكير الابتكاري للطلائع) بمتوسط وزني (2.65)، يليها في الترتيب الثاني (رصد مكافآت وجوائز للطلائع كحوافز لأفكارهم الابتكارية والابداعية) بمتوسط وزني (2.63)، وجاء في نهاية الترتيب (الاستغلال الامثل لكافة الموارد المتاحة فى تنفيذ برامج اكساب الطلائع مهارات التفكير الابتكاري) بمتوسط وزني (2.38)، وهذا ما اكدته دراسة حيث اسفرت نتائجها على ان المنظمات التي (Svensson \& other , 2019 ) تعتمد برامج مهنية واضحة الخطوات والاستراتيجيات ويجد بها تمويل مناسب لسد احتياجات كافى الافراد العاملين بها يساعد على اهداف تلك المنظمة في تتمية الابتكار لاى الفئات التى تستهدفها. مستوي المتطلبات التمويلية المرتبطة بتتمية مهارات التفكير الابتكاري لدي الطلائع كما يحدها الطلائع حيث بلغ المتوسط الوزني (2.52) وهو مستوي (مرتفع) ومؤشرات ذلك وفقاً لترتيب المتوسط لوزني: جاء في الترتيب الأول (رصد مكافآت وجوائز للطلائع كحوافز لأفكارهم الابتكارية والابداعية) بمتوسط وزني (258)، يليها في الترتيب الثاني (وضع نظام للمساءلة على الموارد الموجهة لتمية مهارات التفكير الابتكاري للطلائع) بمتوسط وزني (2.56)، وجاء في نهاية الترتيب (الاستعانة بالخبراء فى كتابة المقترحات التمويلية التى تطور من أداء مركز الشباب تتمية دهارات التفكير الابتكاري للطلائع) بمتوسط وزني (2.43)، واكدت على ذلك دراسة (ابو صالح، 2017) على العديد من النتائج كان اهمها ان بيئة العمل الداخلية بأبعادها المختلفة والتى تشمل(ظروف العمل المادية، الانظمة ، التعليمات، اللوائح، تكنولوجيا المعلومات، المشاركة في اتخاذ القرارات) تؤثر على مستوي الابداع والابتكار. 
(0): المتطلبات التكنولوجية المرتبطة بتنمية مهارات التفكير الابتكاري لاي الطلائع بمراكز الشباب جدول (9) يوضتح المتطلبات التكنولوجية المرتبطة بتنمية مهارات التفكير الابتكاري لدي الطلائع بمراكز الثباب

\begin{tabular}{|c|c|c|c|c|c|c|c|c|c|c|c|c|c|}
\hline \multicolumn{4}{|c|}{ ن = (303) } & \multicolumn{2}{|c|}{ الطلائع } & \multicolumn{2}{|c|}{ ن= (47) } & \multicolumn{4}{|c|}{ |العاملين بمراكز الثباب } & \multirow[b]{2}{*}{ العبارة الع } & \multirow[b]{2}{*}{ P } \\
\hline | ترتيب & المعياري & الوزتوسط & غو غير & لح & موافق & لترتيب & |المعياري & |المتوسطى & مو غير & إلي حد & |موافق & & \\
\hline 4 & 0.776 & 2.43 & 54 & 65 & 184 & 1 & 0.569 & 2.74 & 3 & 6 & 38 & 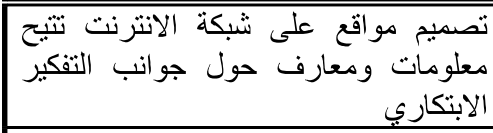 & 1 \\
\hline 5 & 0.754 & 2.42 & 49 & 76 & 178 & 2 & 0.653 & 2.55 & 4 & 13 & 30 & 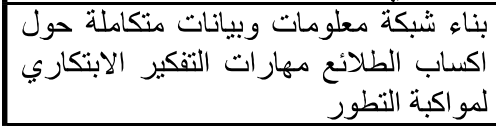 & 2 \\
\hline 3 & 0.733 & 2.43 & 44 & 83 & 176 & 6 & 0.716 & 2.44 & 6 & 14 & 27 & 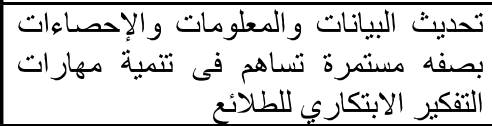 & 3 \\
\hline 2 & 0.670 & 2.49 & 30 & 93 & 180 & 7 & 0.774 & 2.44 & 8 & 10 & 29 & 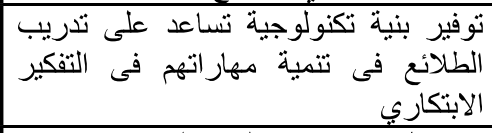 & 4 \\
\hline 1 & 0.699 & 2.52 & 36 & 73 & 194 & 3 & 0.685 & 2.55 & 5 & 11 & 31 & 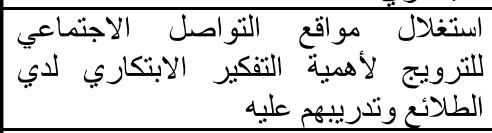 & 5 \\
\hline 6 & 0.727 & 2.38 & 44 & 97 & 162 & 8 & 0.741 & 2.40 & 7 & 14 & 26 & 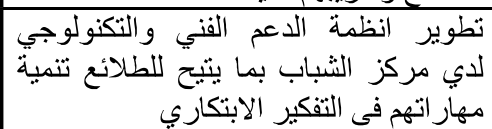 & 6 \\
\hline 7 & 0.733 & 2.36 & 46 & 99 & 158 & 4 & 0.748 & 2.48 & 7 & 10 & 30 & 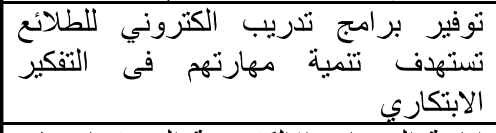 & 7 \\
\hline 8 & 0.749 & 2.31 & 52 & 103 & 148 & 5 & 0.685 & 2.44 & 5 & 16 & 26 & 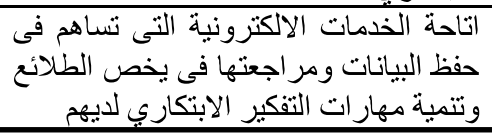 & 8 \\
\hline \multicolumn{6}{|c|}{2.42 مرتفع } & \multicolumn{6}{|c|}{2.51 مرتفع } & \multicolumn{2}{|c|}{ المتوسط الوزنى للبعد ككل } \\
\hline \multicolumn{6}{|c|}{0.529} & \multicolumn{6}{|c|}{0.407} & \multicolumn{2}{|c|}{ الاتحراف المعياري } \\
\hline
\end{tabular}

\section{يوضح الجدول السابق:}

مستوي المتطلبات التكنولوجية المرتبطة بتمية مهارات

التفكير الابتكاري لدي الطلائع بمراكز الشباب كما يحدها العاملين حيث بلغ المتوسط الوزني (2.51) وهو مستوي (مرتفع) ومؤشرات ذلك وفقاً لترتيب المتوسط لوزني: جاء في الترتيب الأول (تصميم مواقع على شبكة الانترنت تتيح معلومات ومعارف حول جوانب التفكير الابتكاري) بمتوسط وزني (2.74)، يليها في الترتيب الثاني (بناء شبكة معلومات وبيانات متكاملة حول اكساب الطلائع مهارات التفكير الابتكاري لمواكبة التطور) بمتوسط وزني (2.55)، وجاء في نهاية الترتيب (تطوير انظمة الدعم الفني 
والتكنولوجي لدي مركز الثباب بما يتيح للطلائع تتمية مهاراتهم فى التثكير الابتكاري) بمتوسط وزني (2.40). - مستوي المنطلبات التكنولوجية المرتبطة بتتمية مهارات التتكير الابتكاري لدي الطلائع

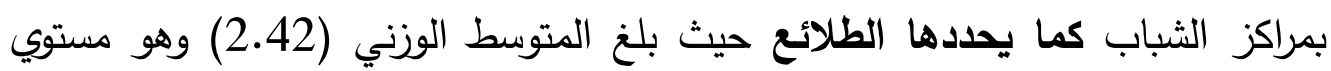
(مرتفع) ومؤشرات ذلك وفقاً لترتيب المتوسط لوزني: جاء في الترتيب الأول (استغلال

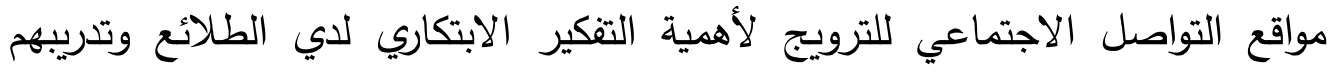

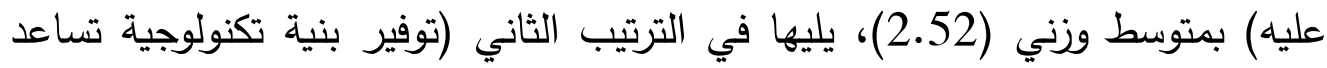

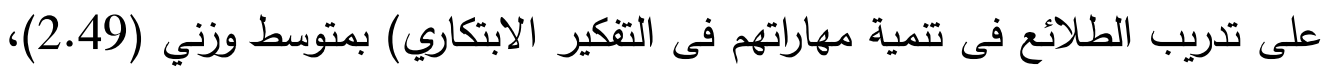
وجاء في نهاية الترتيب (اتاحة الخدمات الالكترونية التى تساهم فى حفظ البيانات

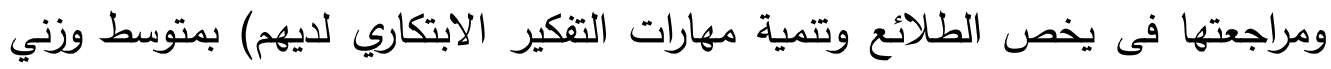

وقد أكدت على نتائج ذلك الجدول نتائج دراسة (المصيلحي، 2010 ) أن فئة النشء والثباب من أكثر فئات المجتمع تأثرا بالثقافات الوافدة أو بالعولمة الثثقافية والتكنولوجيا الحديثة خاصة الإنترنت وما توفره خدمة الثات وتأثيرها على قيم النشء والثباب ومنها قيمة) المشاركة، والانتماء، وتحمل المسئولية الاجتماعية.

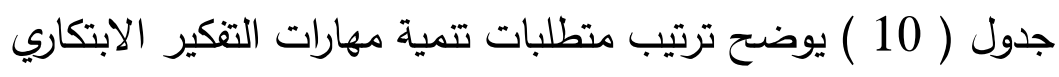

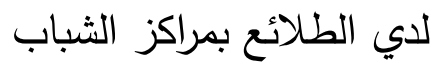

\begin{tabular}{|c|c|c|c|c|c|c|c|}
\hline \multicolumn{2}{|c|}{$(303)=\dot{0}$} & & \multicolumn{3}{|c|}{ العاملين بمراكز الثباب $=$} & \multirow{2}{*}{ المتطلبات } & \multirow[b]{2}{*}{ p } \\
\hline الترتيب & الالاعراري & الوزني & الترتيب & الالاعدران & المزنتي & & \\
\hline 1 & 0.395 & 2.55 & 4 & 0.388 & 2.44 & المتطبات الادارية & $\mathbf{1}$ \\
\hline 3 & 0.426 & 2.50 & 1 & 0.373 & 2.56 & المتطلبات الخاصة بالبرامج & 2 \\
\hline 2 & 0.576 & 2.52 & 2 & 0.517 & 2.55 & المتطلبات التمويلية & 3 \\
\hline 4 & 0.242 & 2.42 & 3 & 0.407 & 2.51 & المتطلبات التكنولوجية & 4 \\
\hline \multicolumn{3}{|c|}{2.49 مرتفع } & \multicolumn{3}{|c|}{2.51 مرتفع } & \multicolumn{2}{|l|}{ متوسط البعد ككل } \\
\hline \multicolumn{3}{|c|}{0.055} & \multicolumn{3}{|c|}{0.054} & \multicolumn{2}{|l|}{ الاتحراف المعياري } \\
\hline
\end{tabular}

يوضح الجدول السابق:

- مستوي ترتيب متطلبات تتمية مهارات التفكير الابتكاري لدي الطلائع بمراكز الثباب كما

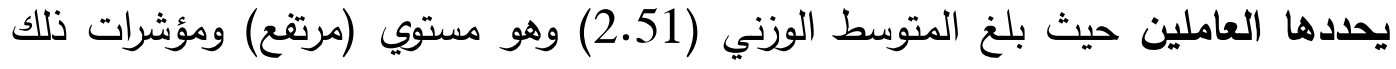

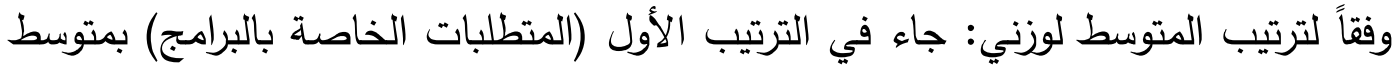


وزني (2.56)، يليها في الترتيب الثاني (المتطلبات التمويلية) بمتوسط وزني (2.56)، وجاء في نهاية الترتيب (المتطلبات الادارية) بمتوسط وزني (2.44).

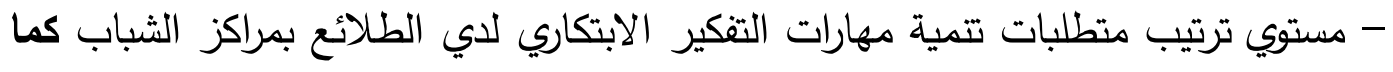

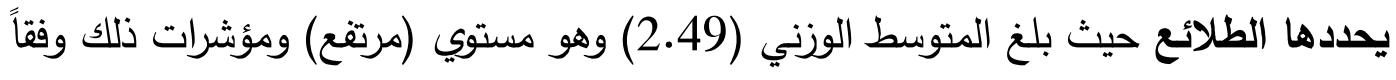

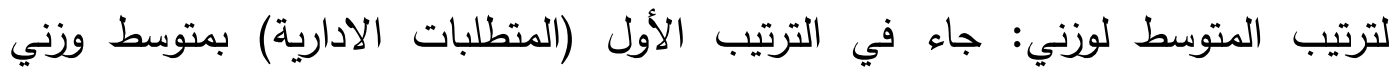

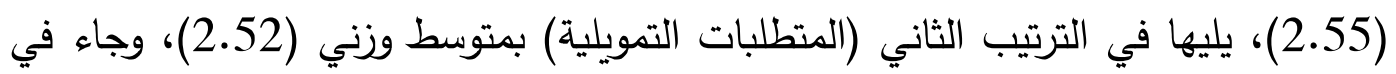

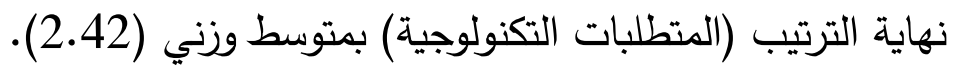

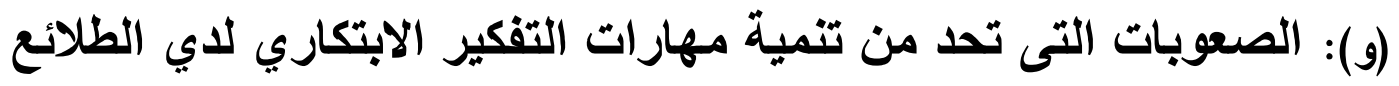
بمراكز الشباب جدول (11) يوضح الصعوبات التى تحد من تتمية مهارات التفكير الابتكاري لدي الطلائع بمراكز

\begin{tabular}{|c|c|c|c|c|c|c|c|c|c|c|c|c|c|}
\hline \multicolumn{3}{|c|}{ ن = (303) } & \multicolumn{3}{|r|}{ الطلائع } & \multicolumn{2}{|c|}{ ن= (47) } & \multicolumn{4}{|c|}{ || العاملين بمراكز الثباب } & \multirow[b]{2}{*}{ العبارة } & \multirow[b]{2}{*}{ r } \\
\hline | - ت لترت & المعياري & الوزتئ & مو غير & إلي حد ما & موافق & لترتيب & المعياري & المتونى & غوافير & إلي حد & موافق & & \\
\hline 10 & 0.786 & 2.25 & 65 & 97 & 141 & 10 & 0.740 & 2.12 & 10 & 21 & 16 & بمركز الثبابت المعارفي بلداهية العاملين & 1 \\
\hline 7 & 0.789 & 2.28 & 63 & 90 & 150 & 8 & 0.805 & 2.29 & 10 & 13 & 24 & 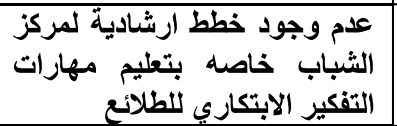 & 2 \\
\hline 6 & 0.785 & 2.39 & 57 & 69 & 177 & 6 & 0.803 & 2.46 & 9 & 7 & 31 & 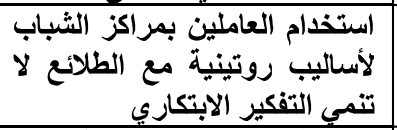 & 3 \\
\hline 4 & 0.743 & 2.44 & 46 & 75 & 182 & 5 & 0.718 & 2.51 & 6 & 11 & 30 & 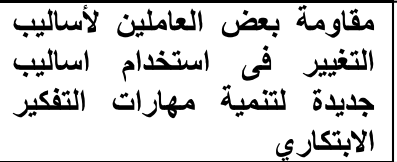 & 4 \\
\hline 8 & 0.809 & 2.27 & 69 & 83 & 151 & 9 & 0.797 & 2.19 & 11 & 16 & 20 & الثبة اعداد العاملين بمراكز & 5 \\
\hline 9 & 0.825 & 2.27 & 73 & 75 & 155 & 7 & 0.741 & 2.40 & 7 & 14 & 26 & ضالثبادية والبشرية داخل مراكز & 6 \\
\hline 5 & 0.730 & 2.40 & 44 & 91 & 168 & 1 & 0.515 & 2.68 & 1 & 13 & 33 & الشبرة اعداد الطلائع داخل مراكز & 7 \\
\hline 3 & 0.734 & 2.45 & 44 & 78 & 181 & 3 & 0.677 & 2.61 & 5 & 8 & 34 & 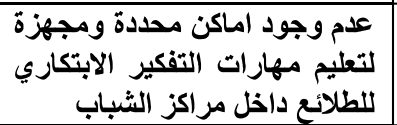 & 8 \\
\hline 2 & 0.670 & 2.50 & 30 & 91 & 182 & 2 & 0.599 & 2.65 & 3 & 10 & 34 & 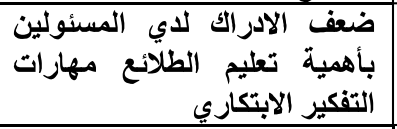 & 9 \\
\hline 1 & 0.673 & 2.54 & 31 & 76 & 196 & 4 & 0.687 & 2.51 & 5 & 13 & 29 & الابتكاريد تقبل & 10 \\
\hline
\end{tabular}




\section{مجلة كلية الخدمة الاجتماعية للار اسات و البحوث الاجتماعية - جامعة ميتم}

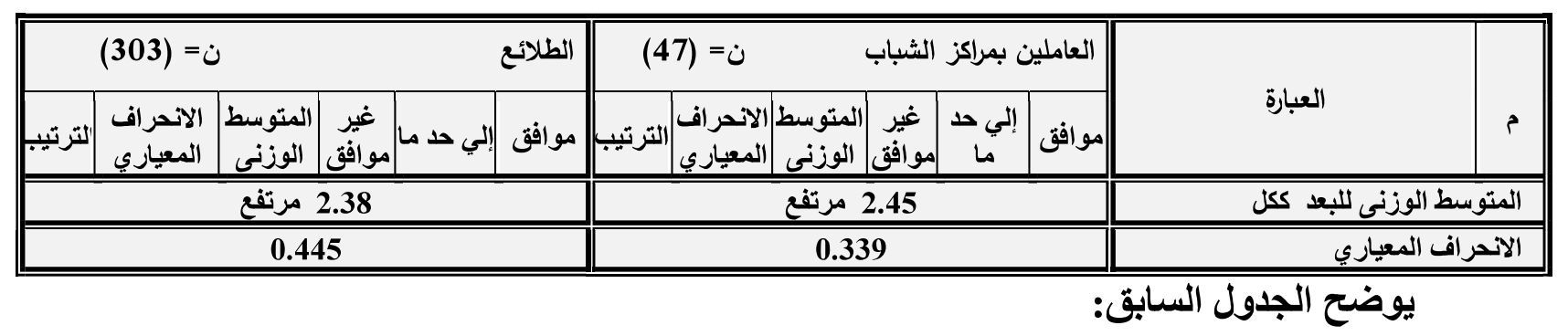

مستوي الصعوبات التى تحد من تتمية مهارات التتكير

الابتكاري لدي الطلائع بمراكز الثباب كما يحدها العاملين حيث بلغ المتوسط الوزني

(2.45) وهو مستوي (مرتفع) ومؤشرات ذلك وفقاً لترتيب المتوسط لوزني: جاء في

الترتيب الأول (كثرة اعداد الطلائع داخل مراكز الشباب) بمتوسط وزني (2.68)، يليها

في الترتيب الثاني (ضعف الادراك لدي المسئولين بأهمية تعليم الطلائع مهارات التفكير

الابتكاري) بمتوسط وزني (2.65)، وجاء في نهاية الترتيب (نقص المعرفة بماهية

مهارات التثكير الابتكاري لدي العاملين بمركز الشباب) بمتوسط وزني (2.12).

- مستوي الصعوبات التى تحد من تتمية مهارات التفكير الابتكاري لدي الطلائع بمراكز الشباب كما يحددها الطلائع حيث بلغ المتوسط الوزني (2.38) وهو مستوي (مرتفع) ومؤشرات ذلك وفقاً لترتيب المتوسط لوزني: جاء في الترتيب الأول (عدم تقبل الطلائع للمهارات الجديدة الخاصة بالتفكير الابتكاري) بمتوسط وزني (2.54)، يليها في الترتيب الثاني (ضعف الادراك لدي المسئولين بأهمية تعليم الطلائع مهارات التفكير الابتكاري) بمتوسط وزني (2.50)، وجاء في نهاية الترتيب (نقص المعرفة بماهية مهارات التفكير الابتكاري لدي العاملين بمركز الشباب) بمتوسط وزني (2.25).

Edward Harowitz ) واتفقت نتائج الجدول مع ما اشارت اليه نتائج دراسية 2009) الى انه يوجد ضعف اهتمام الطلائع بالمشاركة والشعور بالاغتراب بالإضافة إلى الإحباط واللامبالاة الذي يعانوا منها نتيجة الاختلافات بين الثقافات الغربية والمحلية وأوصت لات الدراسة بضرورة غرس بعض القيم في نفوسهم كقيمة المشاركة وتحمل المسئولية واحترام 
(ي): مقترحات تنمية مهارات التفكير الابتكاري لادي الطلائع بمراكز الثباب

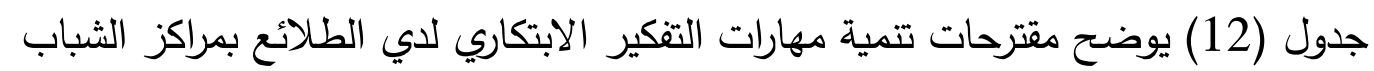

\begin{tabular}{|c|c|c|c|c|c|c|c|c|c|c|c|c|c|}
\hline \multicolumn{4}{|c|}{ ن = (303) } & \multicolumn{2}{|r|}{ الطلائع } & \multicolumn{3}{|c|}{ ن = (47) } & \multicolumn{3}{|c|}{ | العاملين بمراكز الثباب } & \multirow[b]{2}{*}{ العبارة } & \multirow[b]{2}{*}{ p } \\
\hline | لترتيب| & المعياري & | الوزتوسطى & موافقير & إلي حـ & موافق & 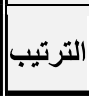 & المعياري & المزتنى & |موافق & & موافق & & \\
\hline 9 & 0.666 & 2.57 & 30 & 69 & 204 & 5 & 0.606 & 2.74 & 4 & 4 & 39 & 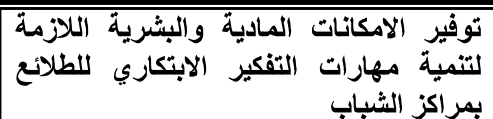 & 1 \\
\hline 7 & 0.660 & 2.58 & 29 & 68 & 206 & 9 & 0.609 & 2.61 & 3 & 12 & 32 & 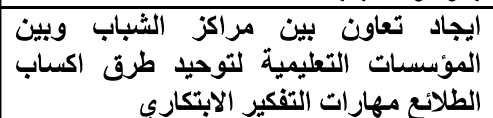 & 2 \\
\hline 2 & 0.590 & 2.64 & 18 & 71 & 214 & 4 & 0.530 & 2.74 & 2 & 8 & 37 & 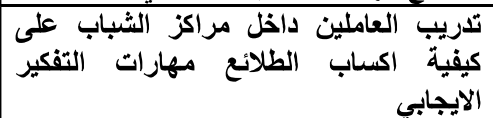 & 3 \\
\hline 5 & 0.657 & 2.60 & 29 & 62 & 212 & 2 & 0.560 & 2.76 & 3 & 5 & 39 & التففير الناقداخ والابتكارب للطلاتع لتدريبهر على & 4 \\
\hline 4 & 0.666 & 2.61 & 31 & 56 & 216 & 10 & 0.616 & 2.57 & 3 & 14 & 30 & 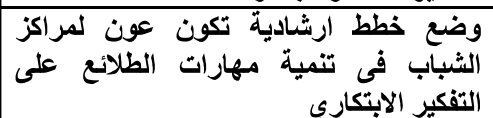 & 5 \\
\hline 6 & 0.623 & 2.59 & 22 & 80 & 201 & 6 & 0.548 & 2.70 & 2 & 10 & 35 & 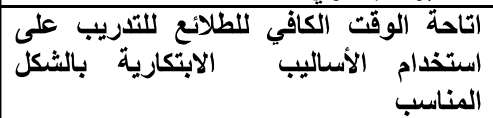 & 6 \\
\hline 8 & 0.630 & 2.57 & 23 & 83 & 197 & 1 & 0.519 & 2.76 & 2 & 7 & 38 & 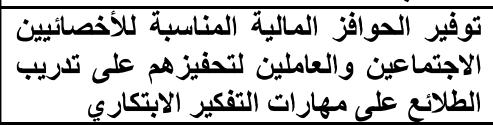 & 7 \\
\hline 1 & 0.590 & 2.66 & 19 & 63 & 221 & 3 & 0.487 & 2.74 & 1 & 10 & 36 & 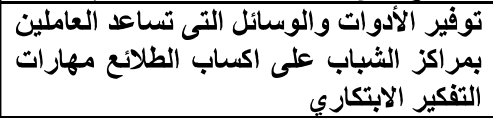 & 8 \\
\hline 10 & 0.648 & 2.55 & 26 & 83 & 194 & 8 & 0.640 & 2.63 & 4 & 9 & 34 & 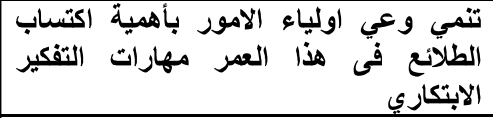 & 9 \\
\hline 3 & 0.579 & 2.61 & 15 & 86 & 202 & 7 & 0.471 & 2.68 & - & 51 & 32 & 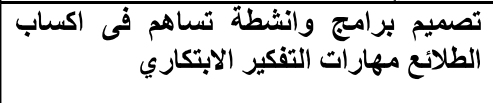 & $\begin{array}{l}1 \\
\mathbf{0}\end{array}$ \\
\hline \multicolumn{6}{|c|}{ 2.60 مرتفع } & \multicolumn{6}{|c|}{ 2.70 مرتفع } & \multicolumn{2}{|c|}{ المتوسط الوزنى للبعد ككل } \\
\hline \multicolumn{6}{|c|}{0.338} & \multicolumn{6}{|c|}{0.286} & \multicolumn{2}{|c|}{ الانحراف المعياري } \\
\hline
\end{tabular}

$$
\text { يوضح الجدول السابق: }
$$

مستوي مقترحات تتمية مهارات التتكير الابتكاري لدي

الطلائع بمراكز الثباب كما يحدها العاملين حيث بلغ المتوسط الوزني (2.70) وهو

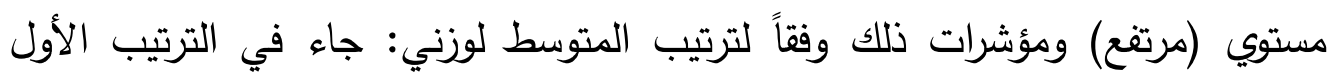
(توفير الحوافز المالية المناسبة للأخصائيين الاجتماعين والعاملين لتحفيزهم على تدريب

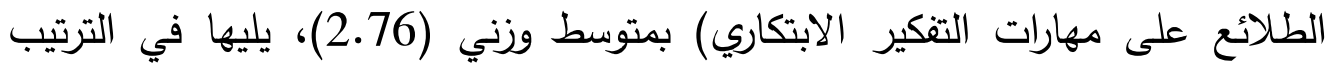




\section{مجلة كلية الخدمة الاجتماعية للار اسات و البحوث الاجتماعية - جامعة لمبرم}

الثاني (توفير المناخ المناسب للطلائع لتدريبهم على التثكير الناقد والابتكار) بمتوسط وزني (2.76)، وجاء في نهاية الترتيب (وضع خطط ارشادية تكون عون لمراكز

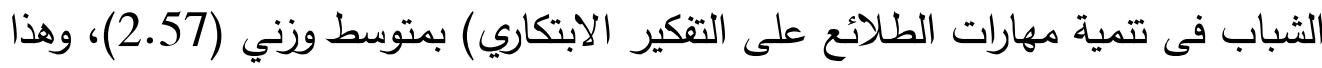

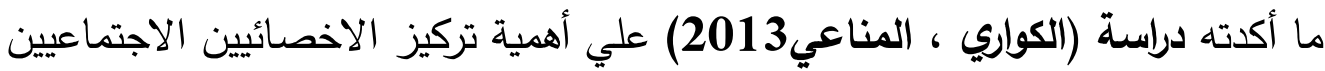

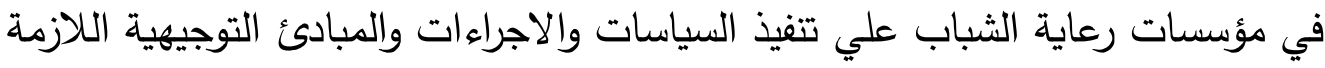

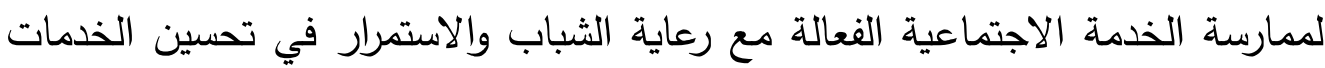

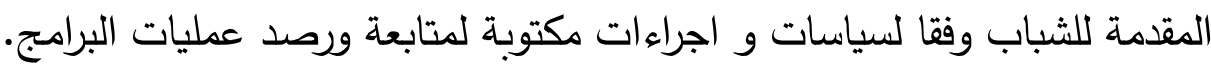

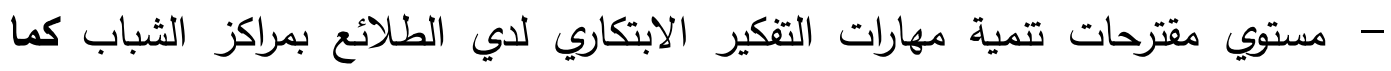

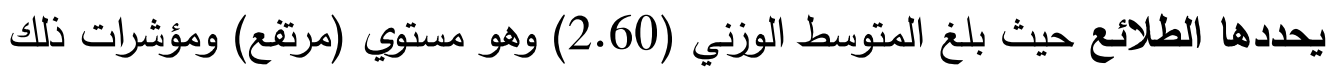

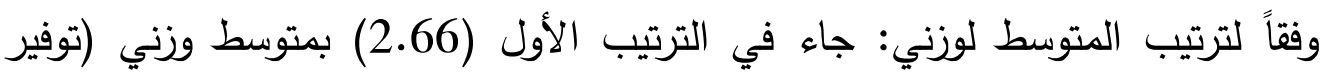
الأدوات والوسائل التى تساعد العاملين بمراكز الثباب على الثئ اكساب الطلائع مهارات

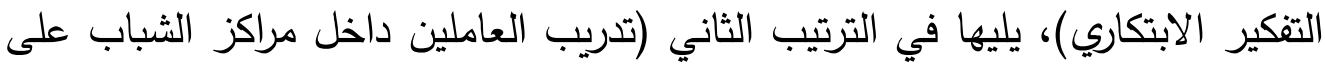

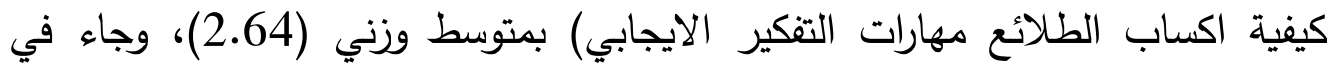

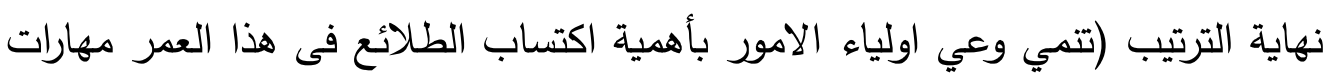
التفكير الابتكاري) بمتوسط وزني (2.55).

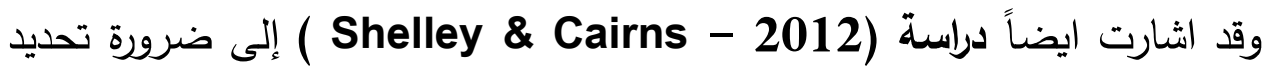

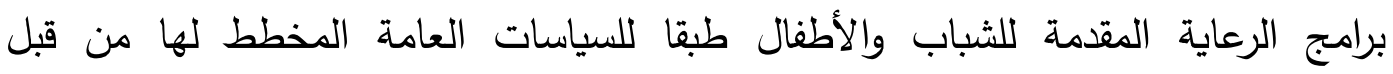

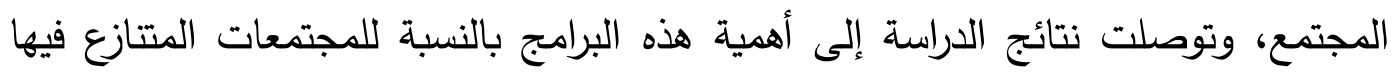

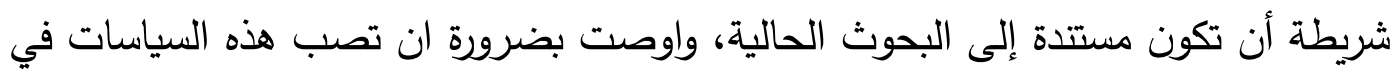

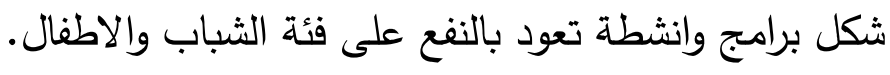

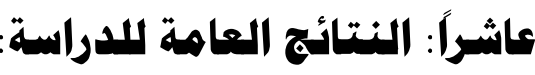

(أ) فيما يتعلق بالإجابة على التساؤل الاول ومؤداه: ما المتطلبات الادارية المرتبطة بتنمية

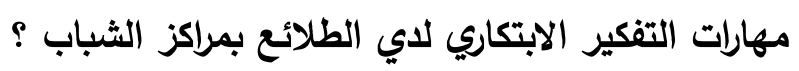
اثبتت نتائج الدراسة أن مستوي المتطلبات الادارية المرتبطة

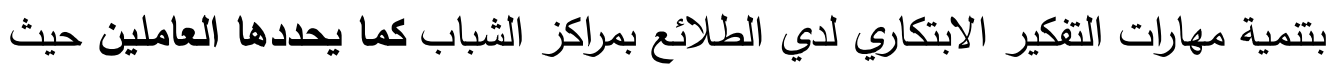

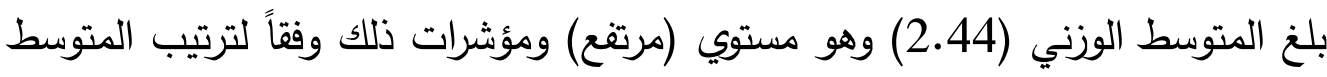
لوزني: جاء في الترتيب الأول (عقد عدد من الثراكات مع مؤسسات مجتمعية مهتمة 


\section{مجلة كلية الخدمة الاجتماعية للار اسات و البحوث الاجتماعية - جامعة لمبرم}

بتتمية مهارات التفكير الابتكاري لدي الطلائع) بمتوسط وزني (2.63)، يليها في الترتيب الثاني (التتسيق بين الموارد المتاحة والاهداف المخططة لتتمية مهارات التنكير الابتكاري للطائع) بمتوسط وزني (2.63)، وجاء في نهاية الترتيب (تنظيم مسابقات

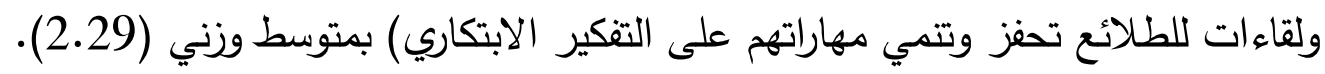

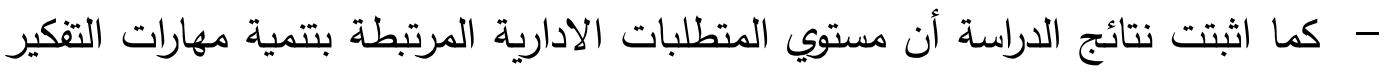

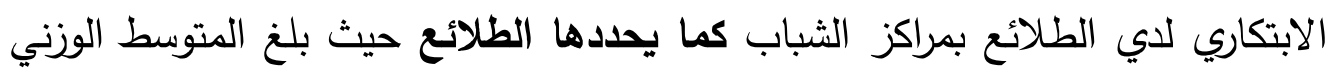

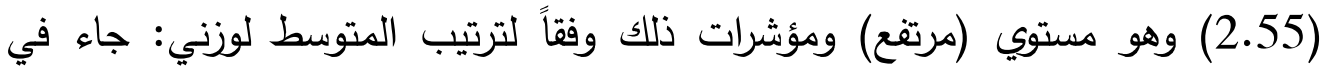
الترتيب الأول (التتسيق بين الموارد المتاحة والاهداف المخططة لتتمية مهارات التثكير

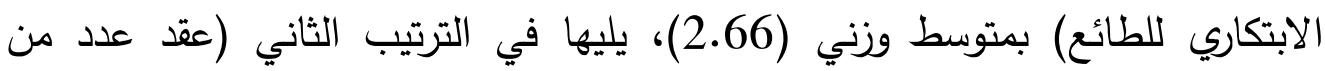
الشراكات مع مؤسسات مجتمعية مهتمة بتمية مهارات التفكير الابتكاري لادي الطلائع) بمتوسط وزني (2.65)، وجاء في نهاية الترتيب (توصيف ادوار العاملين داخل مركز الثباب بشكل دقيق يساهم فى تعليم الطلائع مهارات التفكير الابتكاري) بمتوسط وزني لهني

(ب) فيما يتعلق بالإجابة على التساؤل الثاني ومؤداه: ما المتطلبات الخاصة بالبرامج المرتبطة

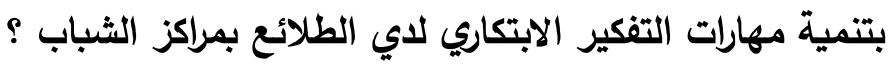

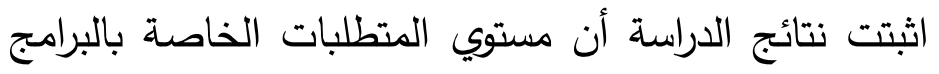
المرتبطة بتتمية مهارات التفكير الابتكاري لدي الطلائع بمراكز الثباب كما يحددها العاملين حيث بلغ المتوسط الوزني (2.56) وهو مستوي (مرتفع) ومؤشرات ذلك وفقاً لترتيب المتوسط لوزني: جاء في الترتيب الأول (دراسة الصعوبات التى تواجه تتفيذ التئ

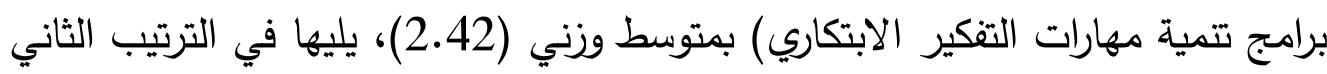

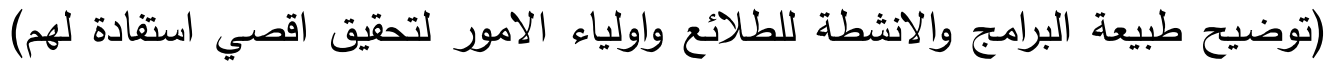

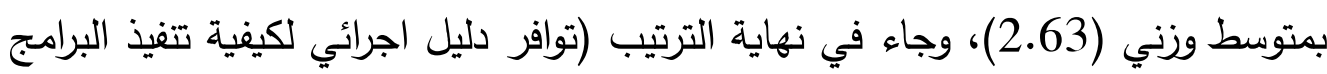

والانثطة الخاصة بتتمية مهارات التنكير الابتكاري للطلائع) بمتوسط وزني (2.40).

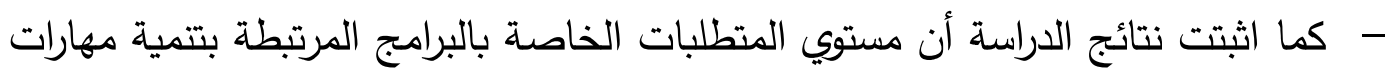
التفكير الابتكاري لدي الطلائع بمراكز الثباب كما يحدها الطلائع حيث بلغ المتوسط

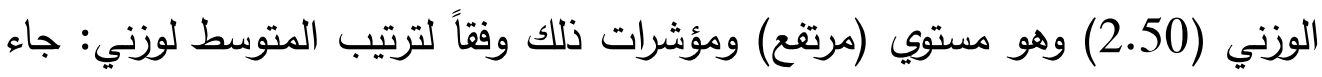
في الترتيب الأول (امتلاك مركز الثباب لأفراد لديها مهارة على تجديد وتطوير البرامج 
الخاصة بتمية التفكير الابتكاري للطلائع) بمتوسط وزني (2.61)، يليها في الترتيب الثاني كلا من (الاستعانة بالمؤسسات المهنية في تصميم برامج تتمية التفكير الابتكاري

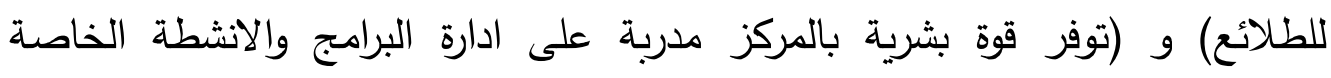

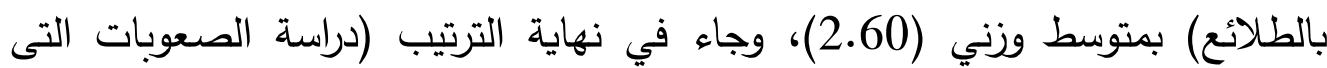
تواجه تتفيذ برامج تتمية مهارات التفكير الابتكاري) بمتوسط وزني ولهي (2.39).

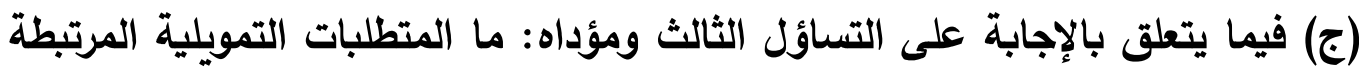
بتنمية مهارات التفكير الابتكاري لاي الطلائع بمراكز الثباب ؟

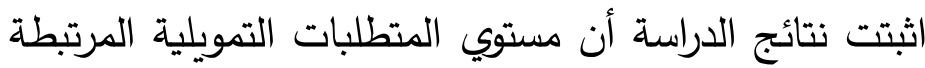
بتتمية مهارات التفكير الابتكاري لدي الطلائع كما يحددها العاملين حيث بلغ المتوسط

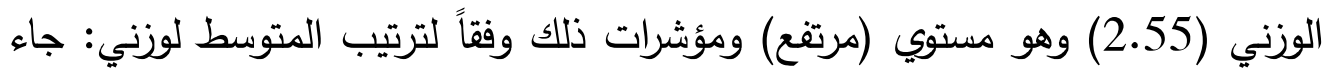
في الترتيب الأول (استثارة المجتمع المحلي للمشاركة في عملية تمويل برامج وانثطة

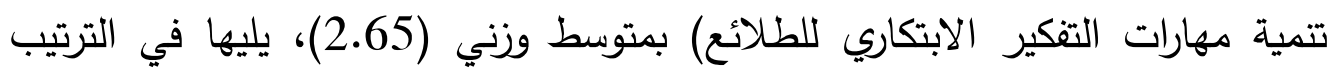
الثاني (رصد مكافآت وجوائز للطلائع كحوافز لأفكارهم الابتكارية والابداعية) بمتوسط ولائية

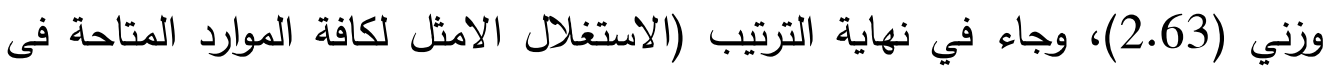
تتفيذ برامج اكساب الطلائع مهارات التفكير الابتكاري) بمتوسط وزني (2.38).

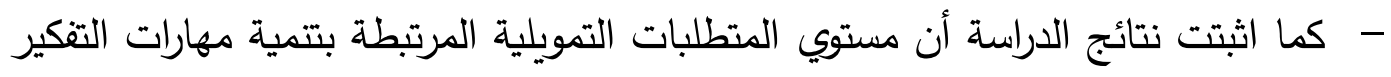

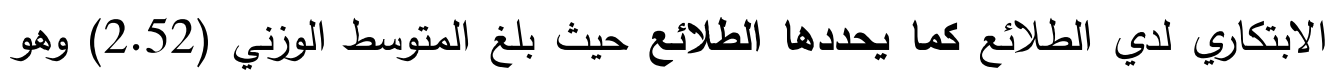
مستوي (مرتفع) ومؤشرات ذلك وفقاً لترتيب المتوسط لوزني: جاء في الترتيب الأول (رصد مكافآت وجوائز للطلائع كحوافز لأفكارهم الابتكارية والابداعية) بمتوسط وزني لئي (258)، يليها في الترتيب الثاني (وضع نظام للمساءلة على الموارد الموجهة لتتمية التحانية

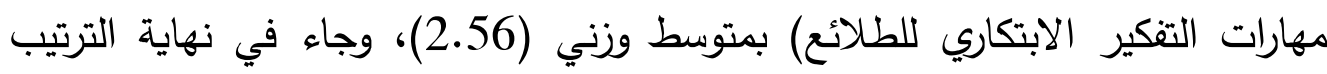

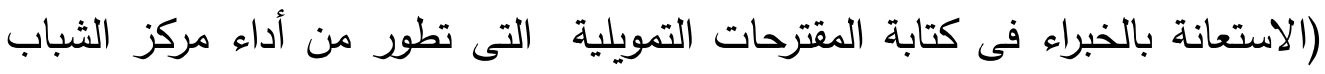
تتمية مهارات التفكير الابتكاري للطلائع) بمتوسط وزني (2.43).

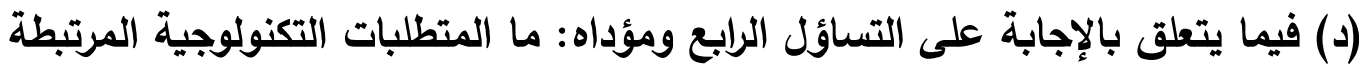

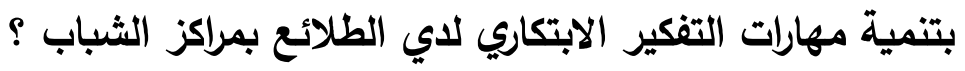
اثبتت نتائج الدراسة أن مستوي المتطلبات لبكيات التكنولوجية المرتبطة بتمية مهارات التفكير الابتكاري لدي الطلائع بمراكز الثباب كما يحدها 
العاملين حيث بلغ المتوسط الوزني (2.51) وهو مستوي (مرتفع) ومؤشرات ذلك وفقاً لترتيب المتوسط لوزني: جاء في الترتيب الأول (تصميم مواقع على شبكة الانترنت تلتيح

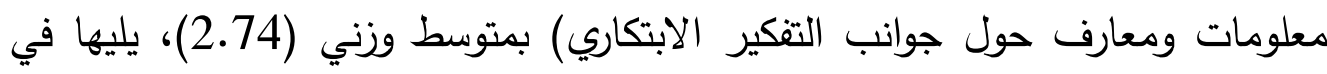

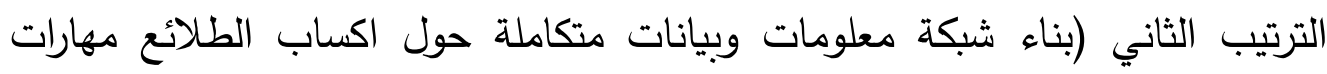
التفكير الابتكاري لمواكبة التطور) بمتوسط وزني (2.55)، وجاء في نهاية الترتيب

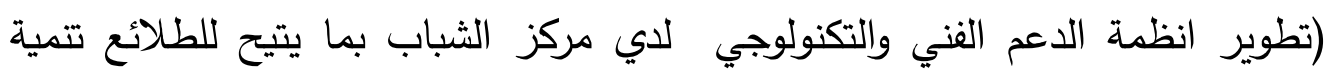
مهاراتهم فى التنكير الابتكاري) بمتوسط وزني (2.40).

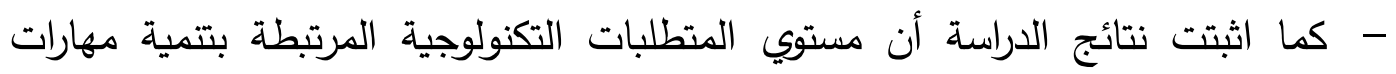

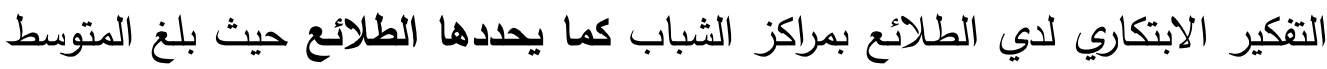

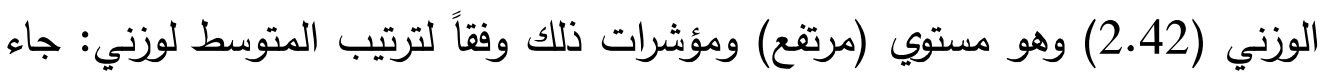
في الترتيب الأول (استغلال مواقع التواصل الاجتماعي للترويج لأهمية التتكير الابتكاري

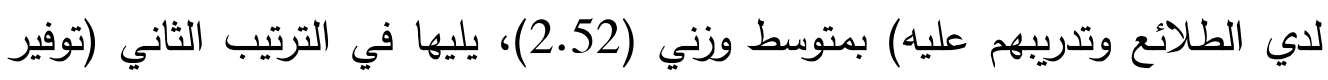
بنية تكنولوجية تساعد على تدريب الطلائع فى تتمية مهاراتهم فى التثكير الابتكاري)

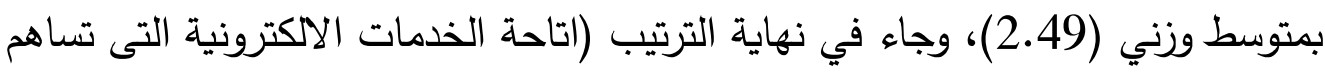

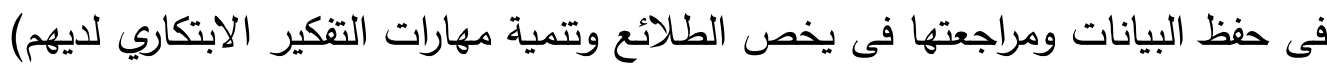

$$
\text { بمتوسط وزني (2.31). }
$$

(ه) فيما يتعلق بالإجابة على التساؤل الخامس ومؤداه: ما الصعوبات التي تحد من

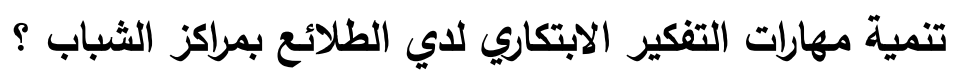

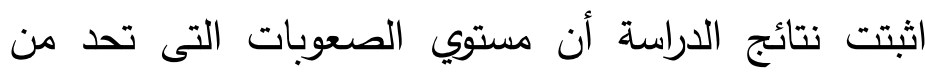

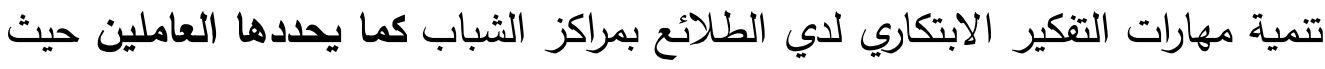

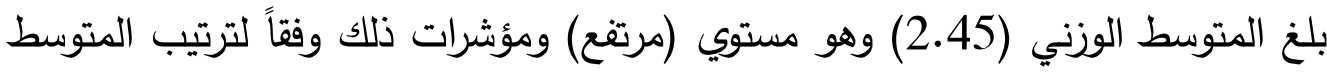

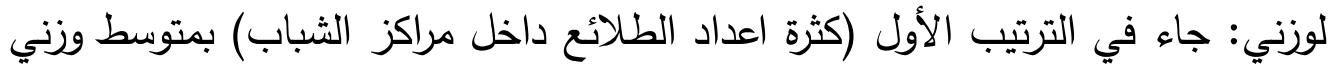

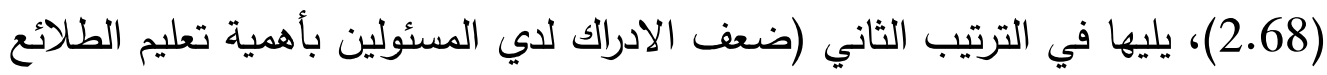

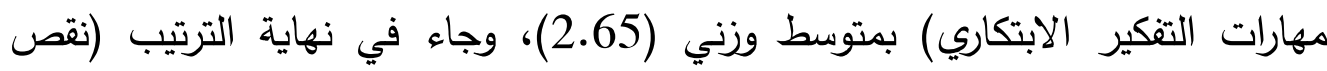

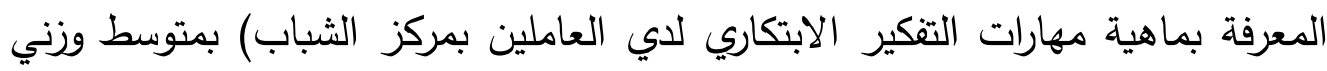


- - - - الابتكاري لدي الطلائع بمراكز الشباب كما يحددها الطلائع حيث بلغ المتوسط الوزني (2.38) وهو مستوي (مرتفع) ومؤشرات ذلك وفقاً لترتيب المتوسط لوزني: جاء في الترتيب الأول (عدم تقبل الطلائع للمهارات الجديدة الخاصة بالتفكير الابتكاري) بمتوسط وزني (2.54)، يليها في الترتيب الثاني (ضعف الادراك لدي المسئولين بأهمية تعليم الطلائع مهارات التفكير الابتكاري) بمتوسط وزني (2.50)، وجاء في نهاية الترتيب (نقص المعرفة بماهية مهارات التقكير الابتكاري لاي العاملين بمركز الشباب) بمتوسط وزني (2.25).

(د) فيما يتعلق بالإجابة على التساؤل السادس ومؤداه: ما مقترحات تنمية مهارات التفكير الابتكاري لدي الطلائع بمراكز الشباب؟ بالجمى

اثبتت نتائج الدراسة أن مستوي مقترحات تتمية مهارات التفكير الابتكاري لدي الطلائع بمراكز الثباب كما يحدها العاملين حيث بلغ المتوسط الوزني (2.70) وهو مستوي (مرتفع) ومؤشرات ذلك وفقاً لترتيب المتوسط لوزني: جاء في الترتيب الأول (توفير الحوافز المالية المناسبة للأخصائيين الاجتماعين والعاملين لتحفيزهم على تدريب الطلائع على مهارات التفكير الابتكاري) بمتوسط وزني (2.76)، يليها في الترتيب الثاني (توفير المناخ المناسب للطلائح لتدربهه على التفكير الناقد والابتكار) بمتوسط وزني (2.76)، وجاء في نهاية الترتيب (وضع خطط ارشادية تكون عون لمراكز الشباب فى تتمية مهارات الطلائع على التفكير الابتكاري) بمتوسط وزني

- كما اثبتت نتائج الدراسة أن مستوي مقترحات تتمية مهارات التفكير الابتكاري لدي الطلائع بمراكز الشباب كما يحدها الطلائع حيث بلغ المتوسط الوزني (2.60) وهو مستوي (مرتفع) ومؤشرات ذلك وفقاً لترتيب المتوسط لوزني: جاء في الترتيب الأول (2.66) بمتوسط وزني (توفير الأدوات والوسائل التى تساعد العاملين بمراكز الثباب على اكساب الطلائع مهارات التقكير الابتكاري)، يليها في الترتيب الثاني (تدريب العاملين داخل مراكز الشباب على كيفية اكساب الطلائع مهارات التفكير الايجابي) بمتوسط وزني (2.64)، وجاء في نهاية الترتيب (تتمي وعي اولياء الامور بأهمية اكتساب الطلائع فى هذا العمر مهارات التفكير الابتكاري) بمتوسط وزني (2.55). 


\section{مجلة كلية الخدمة الاجتماعية للار اسات و البحوث الاجتماعية - جامعة ميتم}

\section{حادي عشر: رؤية هستقبلية لطريقة تنظيم المتتهـع لتنهيسة ههـارات التفكير الابتكاري لدي الطلائع بمراكز الشباب} أ) الهداف الرؤية المستقبلية.

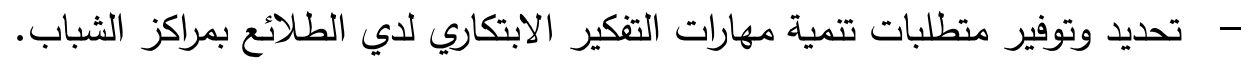
- - مضع اليات عمل مراكز الثباب لتحقيق هدف تتمية مهارات التنكير الابتكاري لدي الطلائع.

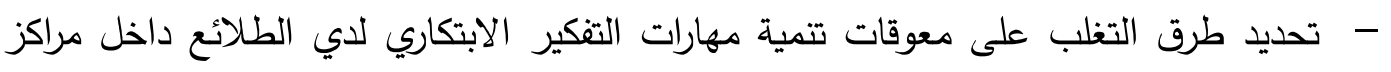
الثباب.

ب)|(الموجهات النظرية للـؤية: (1) نظرية التحكم العقلي الذاتي(لستيرنبرج): تري النظرية على ان الاشخاص يكون لديهم العديد من الاساليب وليس اسلوبا واحدا

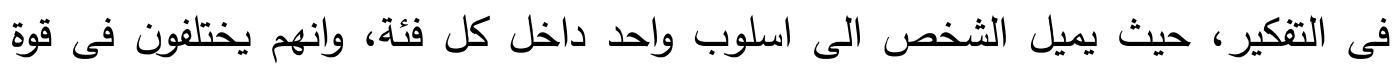
تفضيلهم ومرونتهم لأساليب التفكير ، ويخلطون بين ملائمة الاسلوب ومستويات القدرة لذلك الكي فأن اساليب التثكير لها نفس الاثكال والميول والدجال لدي كل شخص، ولهن وهذه الاساليب

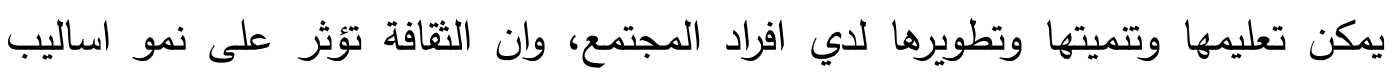
التفكير وتقوم نظرية التحكم العقلي الذاتي على ان اساليب التفكير تقسم الى ثلاثة مجموعات كما يلي: - مجموعة تتضمن تتفيذ الاشياء بأبداع مما يدل على مستويات عليا معقدة من الجانب

$$
\text { المعرفي وتشمل (المتحرر -الحكمي0 الهرمي- العالمي -التشريعي). }
$$

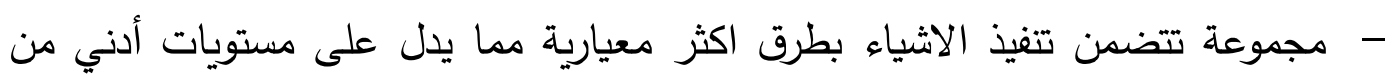

$$
\text { التعقيد المعرفي وتثمل (التتفيذي- المحلي- المحافظ -الملكي). }
$$

- مجموعة تشمل الاساليب التقليدية فى التفكير منها ( السطحي -الفوضوي- الداخلي).

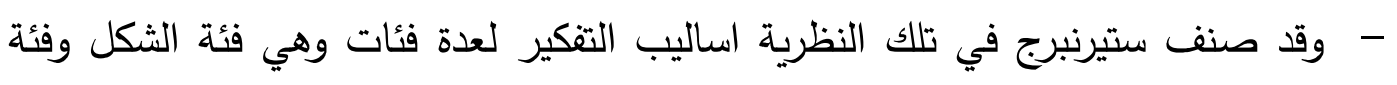
الوظيفة وفئة النزعة وفئة المجال وفئة المستوي وتثمل كل فئة على عدة اساليب للتنكير 


\section{مجلة كلية الخدمة الاجتماعية للار اسات و البحوث الاجتماعية - جامعة تمير}

\section{(2) نموذج العمل مع مجتمع المنظمة:}

يهدف تلك النموذج الى التعامل المهني مع مكونات المنظمة الاجتماعية ومجتمعها الذاتي لمساعدتها على خدمة فئتها بفاعلية متزايدة، ويقوم النموذج على فلسفة محددة وهي اهمية التعقى داخل المنظمة ودراستها وذلك للوقوف على النواحي السلبية والايجابية لها، معالجة النواحي السلبية وتدعيم الجوانب الايجابية داخل المنظمة.

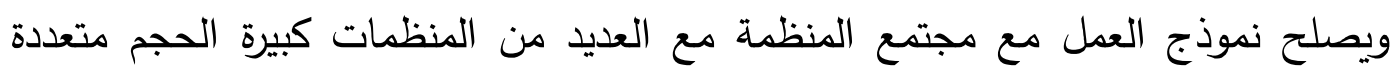

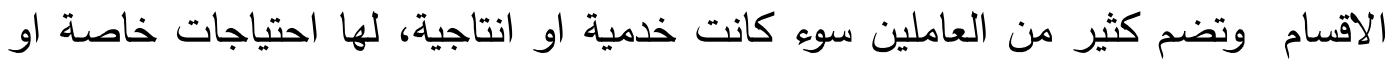

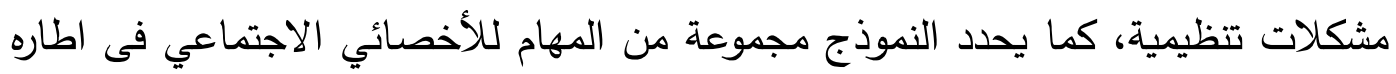

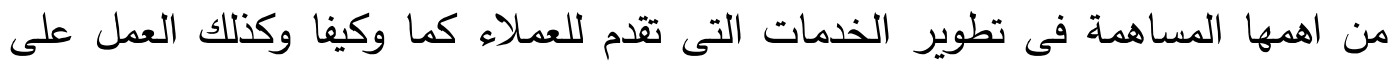

توفير الظروف الملائمة داخل تلك المنظمة التى يعمل بها. ج)الاستراتيجيات والتكتيكات المهنية لطريقة تنظيم المجتمع والتى يمكن الاستفادة منها فى لفئي الرؤية: - - - - - الاطراف المعنية تتمية مهارات التنكير الابتكاري لدي النشء والطلائع ( وذلك من خلال عقد الندوات، والمؤتمرات، والمناقشات).. - استراتيجية التوفير والإتاحة : فالهدف العام في هذه الاستراتيجية "توفير قاعدة البيانات

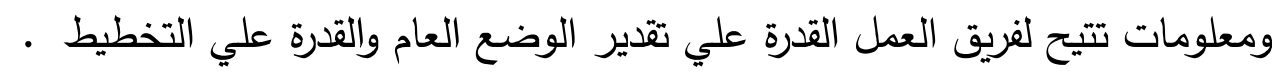
- استراتيجية التنسيق: وذلك لتحقيق التسيق والتعاون بين جميع الاجهزة والمنظمات

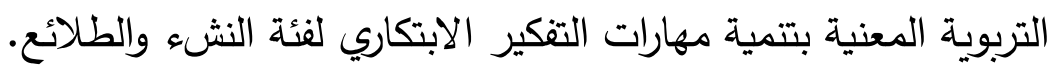

د) آليات تنفيذ الروئية المستقبلية:

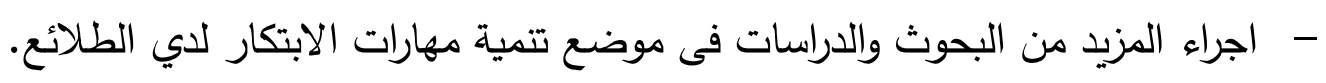

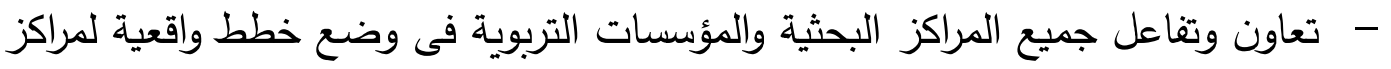

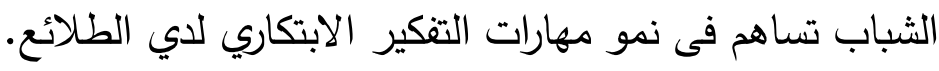

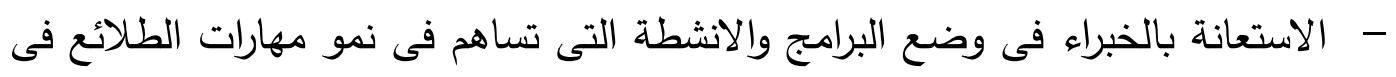

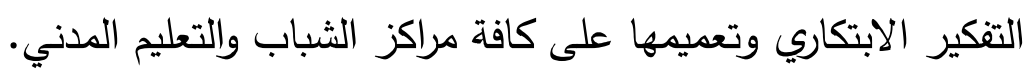

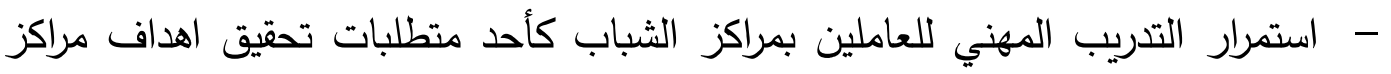
الثباب فى غرس وتتمية مهارات التنكير الابتكاري. 
- - - - - - داخل انشطة وبرامج المراكز .

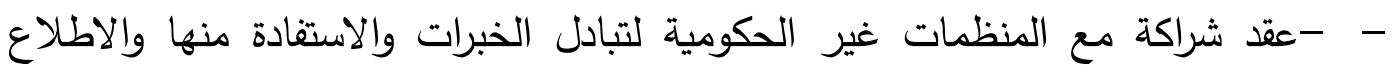
على التجارب الناجحة فى مجال اكساب النشء مهارات التفكير الابتكاري. - - - - - للعاملين او الطلائع. - انثاء وحدة داخل كل مركز شباب تكون مسئولة عن تبني الافكار الابتكارية وتثجيعها بما يساهم فى نشر التقكير الابتكاري داخل مراكز الثباب.

هـ) متطلبات نجاح مراكز الثباب فى التعامل مع الطلائع وتنمية مهارتهم فى التفكير الابتكارى:

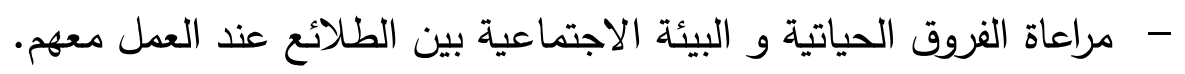

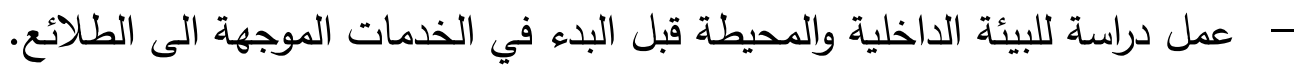
- اشراك الاهل في تطوير وتتمية مهارات الطلائع .. - توفير الموارد والامكانيات اللازمة لتمكين مراكز الشباب من تحقيق اهدافها.

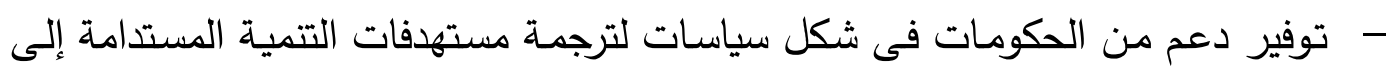

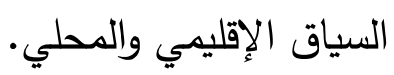
- تعزيز قدرة المجتمع المدني بشكل عام على الدخول في حوار مـع الحكومات بشأن ضمان أن تكون القوانين والسياسات ذات الصلة مُراعية للطلائح.

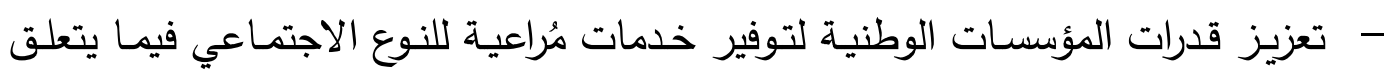
بالرعاية الاجتماعية للطلائع المبتكرين. - - المرونة وفقا للمتغيرات المستجدة. - مراعاة القيود المختلفة (مادية - بشرية - تشريعية ). - - التقييم المرحلي والمستمر لبرامج وانثطة مراكز الثباب من خلال تتبع ومراجعة العلاقة بتهنة

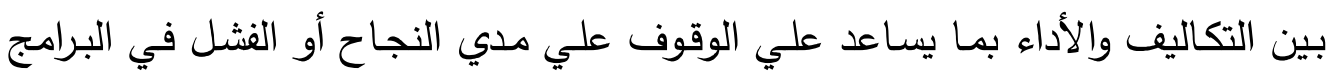

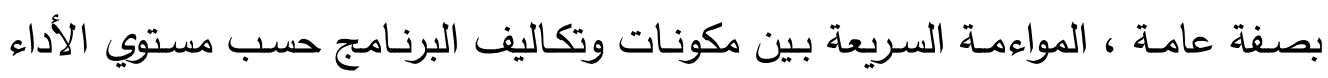
فيه.

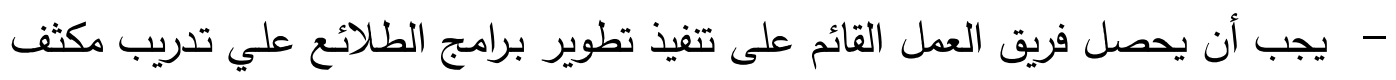
علي الطرق الحديثة التي تقوم بتقديم النصح والإرشاد عند الضرورة. 


\section{مجلة كلية الخدمة الاجتماعية للار اسات و البحوث الاجتماعية - جامعة مـ}

\section{هراجع الدراسة}

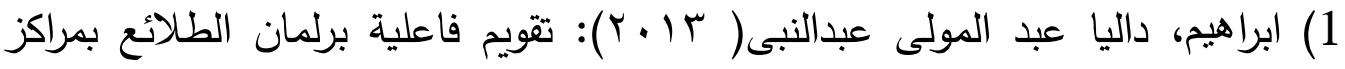
الثباب فى تحقيق أهدافه، رسالة ماجستير غير منشورة ، جامعة الفيوم، كلية الخدمة

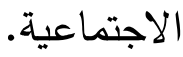

2) ابن منظور (2010) : لسان العرب ، بيروت ، دار صادر للنشر .

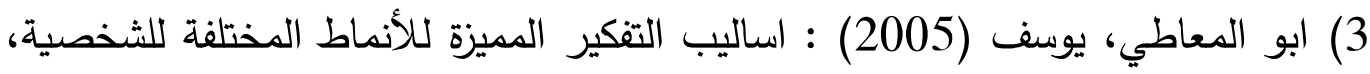

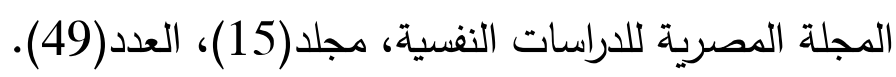

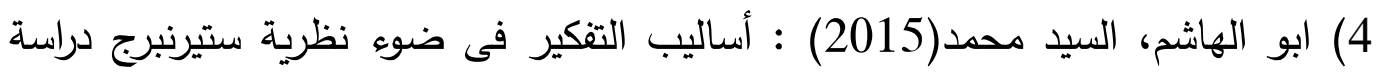

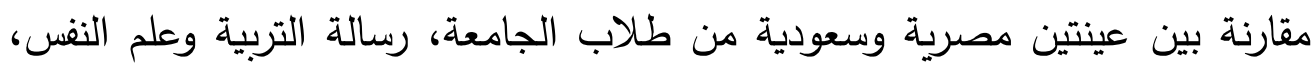

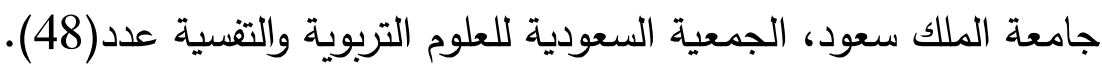

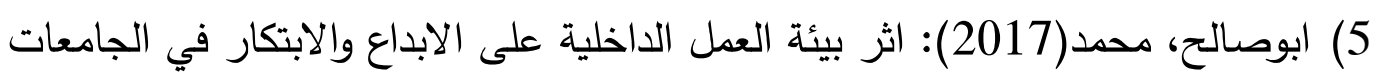

الاردنية الخاصة، رسالة ماجستير غير منشورة، كلية الاعمال، جامعة عملن العببية.

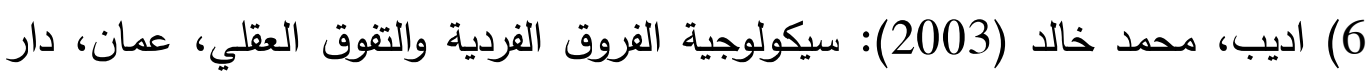
وائل. 7) أنس، عادل محمد (2004) :اتجاهات في ممارسة طريقة تنظيم المجتمع في مرحلة

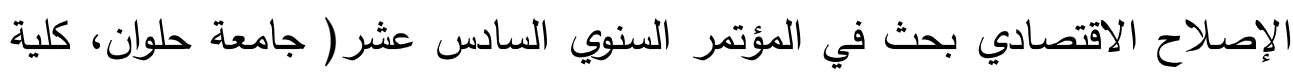

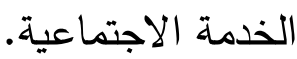

8) البعلول، المؤمن ابراهيم(2012): علاقة دافعية الانجاز ومستوي الطموح بالتفكير

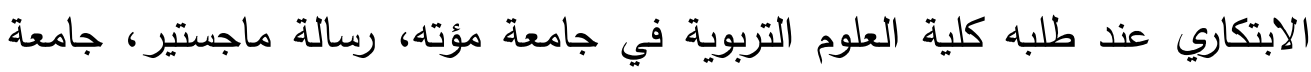
مؤته، الاردن. - مابكاري 9) الحسيني ، عبد الناصر الأشعل(2010)، تتمية التقكير الابتكارى باستخدام برنامج سكامبر ، بحث منشور في مركز دراسات وبحوث المعوقين، المملكة العربية السعودية.

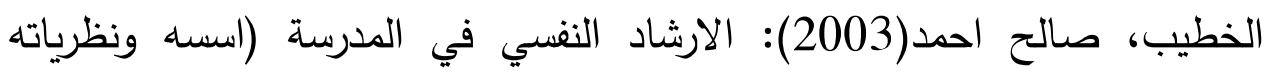
وتطبيقاته)، دار الكتاب الجامعي، الامارات المتحدة. 
1الدبش، عمران محمد على (2011) :فاعلية برنامج قائم على اسلوب التقكير

الابداعي في تدريس مبحث التربية الوطنية لرفع مستوي التحصيل لطلبة الصف التاسع

الاساسي فى محافظة رفح، رسالة دكتوراة غير منشورة كلية التربية، جامعة الازهر

الدردير، عبدالمنعم احمد، الطيب، عصام على (2006): اساليب التفكير نظريات

ودراسات وبحوث معاصرة، القاهرة ، مكتبة الانجلو المصرية.

13) الزقاوي، نادية مصطفى (2001): القدرة على التفكير الابتكارى في علاقتها باقيم

وبعض المتغيرات السيكوسوسيولوجية الاخري لدي عينة من طلبة الجذع المشترك

بمعهد علم النفس جامعة وهران بالجزائر، مجلة العلوم الانسانية، جامعة منتورى قسنطينة، عدد15.

14) الزيات، فاطمة محمود (2009) : علم النفس الإبداعي ،دار المسيرة للنشر والتوزيع والطباعة عمان الاردن، الطبعة الاولى.

الطيطي، محمد حمد (2011) : تتمية قدرات التفكير الابداعي، دار المسيرة للنشر

والتوزيع والطباعة، عمان الاردن.

16) الفحل، طارق إسماعيل (2003) :مدى إشباع احتياجات الأطفال في أندية الطلائع، بحث منشور في المؤتمر العلمي الخامس عشر" الرعاية الاجتماعية وحقوق الإنسان،( جامعة القاهرة، كلية الخدمة الاجتماعية 10-11 مايو.

القلا، فخر الدين(2006): طرائق التدريس العامة فى عصر المعلومات، العين، دار

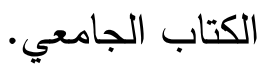

الكواري ،كلثم ، المناعي، صلاح: (2013)، رعاية الثباب في المجتمع العربي

"أسس وتطبيقات" ، المكتب الجامعي الحديث، الاسكندرية .

المصيلحي ، نجلاء أحمد :(2010)الآثار السلبية لثقافة الشات على القيم

الاجتماعية لدى الثباب الجامعي وتصور مقترح من منظور الممارسة العامة في الخدمة الاجتماعية للتحقيق من حدتها بحث منشور في مجلة دراسات في الخدمة الاجتماعية والعلوم الإنسانية،( جامعة حلوان، كلية الخدمة الاجتماعية، ج 2، العدد التاسع والعشرين، أكتوبر •

20) بدوي، احمد ذكي(1998) : معجم مصطلحات العلوم الاجتماعية، بيروت، مكتبة البستان. 


\section{مجلة كلية الخدمة الاجتماعية للار اسات و البحوث الاجتماعية - جامعة مـ}

21) جاد الله، السيد حسن البساطي ( 1 ( † ) : برنامج مُقترح من منظور الممارسة العامة للخدمة الاجتماعية في تتمية وعي الثباب الجامعي بالأمن الفكري، القاهرة، بحث منشور، الجمعية المصرية للأخصائيين الاجتماعيين، مجلة الخدمة الاجتماعية، $.09 \varepsilon$

22) جمل محمد مجاهد(2005): تتمية مهارات التفكير الابتكاري ، دار الكتاب الجامعي، العين، الامارات.

23) رجب، ابراهيم عبدالرحمن، واخرون (1997): نماذج ونظريات تتظيم المجتمع، القاهرة، دار الثقافة للطبع والنشر •

24) رشوان، حسن(2006) ممارسة الخدمة الاجتماعية في مجال رعاية الثباب

$$
\text { وقضاياهم، المكتب الجامعي الحديث. }
$$

25) رضا، عبدالحليم (2000) : تتظيم المجتمع النظرية والتطبيق، القاهرة، كلية الخدمة

$$
\text { الاجتماعية. }
$$

26) ريان، محمد هاشم(2006):مهارات التفكير وسرعة البديهة وحقائب تدريبية، الاردن، مكتبة الفلاح للنشر والتوزيح.

زيدان، فاطمة شحاتة أحمد(2004) : مركز الطفل في القانون الدولي، دار الخدمات الاجتماعية، القاهرة.

28) سرايا، عادل(2007): تكنولوجيا التعليم المفرد وتتمية الابتكار رؤية تطبيقية،

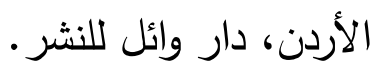

29) سلام، اسماعيل مصطفى (2000) : معوقات الاعداد العلمي والمهني للأخصائي الاجتماعي الذي يعمل مع المشكلات الاسرية، المؤتمر الحادي عشر، كلية الخدمة الاجتماعية، الفيوم. 30) شعبان، يسري (2010) :عائد استخدام الممارسة المهنية لطريقة تتظيم المجتمع في مجال رعاية الثباب، بحث منشور في مجلة دراسات في الخدمة الاجتماعية والعلوم الإنسانية، كلية الخدمة الاجتماعية، جامعة حلوان، القاهرة.

31) صابر، هيام حمدي (2011): التدخل المهني لطريقة تنظيم المجتمع لتتمية المعارف والمهارات المهنية لطلاب الخدمة الاجتماعية المتدربين بمراكز الشباب، بحث 
منشور في مجلة دراسات الخدمة الاجتماعية والعلوم الإنسانية، العدد 31 ،المجلد 8 ،كلية الخدمة الاجتماعية، جامعة حلوان، القاهرة. 32) عباس، محمد جابر (2018): دور منظمات التعليم قبل الجامعي في تتمية الابتكار لاى الطلاب دراسة مطبقة على المنظمات الثريكة ببرنامج تتمية مهارات البحث العلمي بمحافظة أسوان، بحث منشور بالجمعية المصرية للأخصائيين الاجتماعيين،

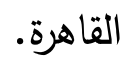

33) عبد العزيز، سعي(2006): المدخل إلى الإبد اع ، دار الثقافة للنشر، عمان.

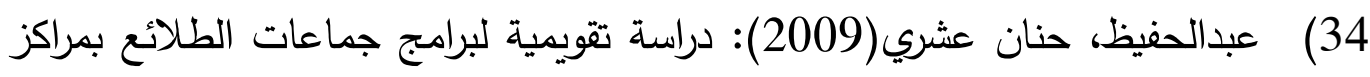

الثباب، رسالة ماجستير، غير منشورة، جامعة حلوان، كلية الخدمة الاجتماعية.

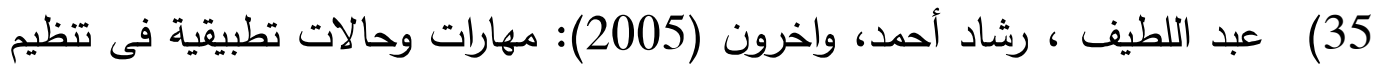

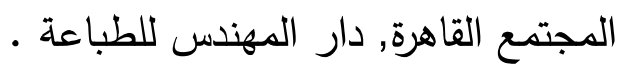
36) عبداللطيف، رشاد احمد (2001) : اسس طريقة تتظيم المجتمع فى الخدمة الاجتماعية، مدخل دراسة المجتمع، القاهرة ، دار جنيدي.

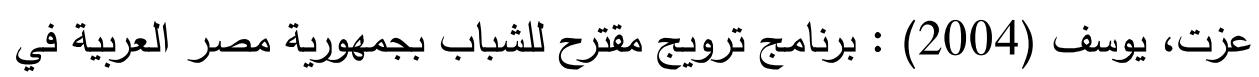

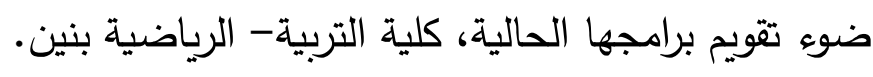

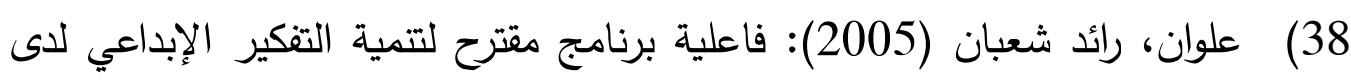

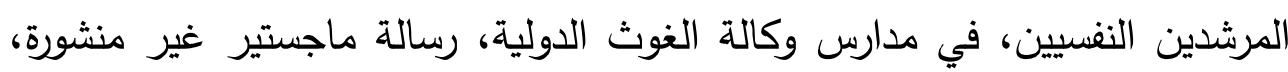
كلية التربية، الجامعة الاسلامية، غزة. 39) قطامي، نايفة (2001): تعليم التنكير للمرحلة الاساسية، عمان، الأردن، دار الفكر للطباعة والنشر . تمطي

40) محمد، محمد عبد الفتاح(2007): الخدمة الاجتماعية فى مجال تتمية المجتمع ولئم المحلى - أسس نظرية ونماذج تطبيقية (القاهرة , الدكتب العلمى للنشر والتوزيع • مرسال، غازي (2010): التقكير الابداعي، دار جليس زمان، عمان. موسي، رشاد على عبدالعزيز، الحطاب، سهام احمد (2004): الابتكار، القاهرة، دان، دمان،

$$
\text { دار الفكر العربي. }
$$

43) Carney, B. R. (2009) : generational attitudes, perceptions, and preferences toward organizational creativity and innovation ,doctoral dissertation, saybrook university. 
44) David, Phipps, Johanne, Provencal, Naomi, Nichols, Allyson, Hewitt:(2012). Knowledge Mobilization and Social Innovation are Integral Components of Innovation Strategies to Leverage Investments in Higher Education. Submitted to the Social Sciences and Humanities Research Council Knowledge Synthesis. York University: Toronto. Canada.

45) Edward Horowitz (2009): Citizenship and youth in postcommunist Poland: the role of communication inpolitical socialization, PHD (The University of Wisconsin.

46) Elias, A. \& Edward, E. (2004). Modern DictionaryEnglish/Arabic. Modern Publishing House,Cairo, Egypt.

47) G.walsh \& others (2011): thinking skills in the early years-a guide for practitioners, stranmillies university, college of the queen's university of belfast.

48) Leiterman Hanah(2013): Youth sumitit slaw relate Education For violence presentation (Canada, university of Tornot.

49) Ngaik. (2005). Do a dynamics of the life values of rules youth. Russian Education \& Society, V. (48), N.(2):46 - 68

50) Oxford dictionary (1993): clarendo press, United kingdom

51) Robbins, S. P. (2005). Organizational behavior. Upper Saddle River, NJ: Pearson Prentice Hall.

52) Shelley McKeown ,Ed,Cairns,2012:-Peacemaking youth programmers in Northern Ireland, journal of Aggression conflict and peace Research, Vol.4ISS:2,.

53) Sternberg, R. (1994). Allowing for Thinking styles. Educational Leadership, (52),(3).

54) Sternberg, R. (1997). Thinking Styles. New York: Cambridge University Press.

55) Sternberg, R. (2002). Cognitive Psychology. Boston, MA: Allyn \& Bacon.

56) Sternberg, R. (2007). Thinking Styles. New York: Cambridge University Press.

57) Svensson, Per, Andersson, Fredrik, Mahoney, Tara Jae-Pil (2019):Antecedents and outcomes of social innovation: A global study of sport for development and peace organizations, Sport Management Review,ISSN 1441-3523, https://doi.org/10.1016/j.smr.2019.08.001.

58) Webster dictionary (1991):, new york, lexicon publications, ins. 
59) Wilson. R. F. (2007), the Relationship between the Organizational Climate of Secondary Schools and .Creative Thinking. Journal of Psychological Studies Vole. 15. No. 3.

60) Zhang, L. (2002). Thinking Styles: Their relationship with modes of thinking and academic performance. Educational Psychology,(22).

61) Zorkaia, N. \& Diuk, M. (2004). Values and attitudes of young Russian. Russian Social Science Review, Sep(45),(5). 